Prepared in cooperation with the National Park Service

Water and Sediment Chemistry of Selected Existing and Potential Habitats of the Mohave Tui Chub, Mojave National Preserve, California, 2018

Scientific Investigations Report 2021-5106 
Cover: Lake Tuendae at the Soda Springs Complex at Zzyzx in Mojave National Preserve, California. Photograph taken by Katherine J Earp, May 2018. 


\section{Water and Sediment Chemistry of Selected Existing and Potential Habitats of the Mohave Tui Chub, Mojave National Preserve, California, 2018}

By Katherine J. Earp and Angela P. Paul

Prepared in cooperation with the National Park Service

Scientific Investigations Report 2021-5106 


\section{U.S. Geological Survey, Reston, Virginia: 2021}

For more information on the USGS - the Federal source for science about the Earth, its natural and living resources, natural hazards, and the environment—visit https://www.usgs.gov or call 1-888-ASK-USGS.

For an overview of USGS information products, including maps, imagery, and publications, visit https://store.usgs.gov/.

Any use of trade, firm, or product names is for descriptive purposes only and does not imply endorsement by the U.S. Government.

Although this information product, for the most part, is in the public domain, it also may contain copyrighted materials as noted in the text. Permission to reproduce copyrighted items must be secured from the copyright owner.

Suggested citation:

Earp, K.J., and Paul, A.P., 2021, Water and sediment chemistry of selected existing and potential habitats of the Mohave tui chub, Mojave National Preserve, California, 2018: U.S. Geological Survey Scientific Investigations Report 2021-5106, 26 p., https://doi.org/10.3133/sir20215106.

Associated data for this publication:

U.S. Geological Survey, 2021, National Water Information System: U.S. Geological Survey web interface, https://doi.org/10.5066/F7P55KJN.

ISSN 2328-0328 (online) 


\section{Contents}

Abstract

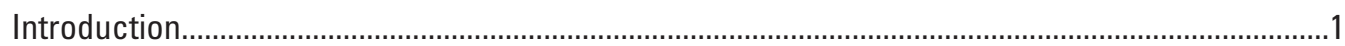

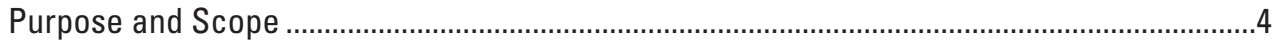

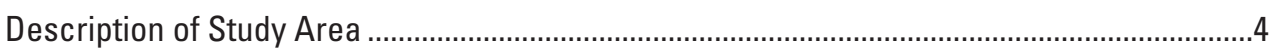

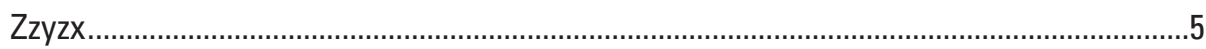

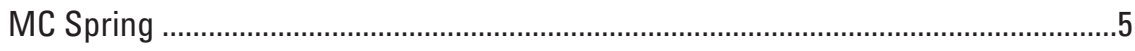

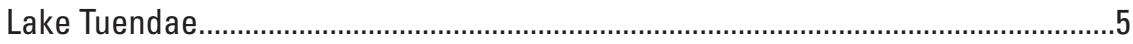

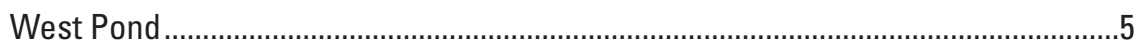

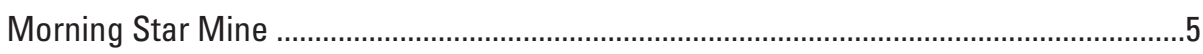

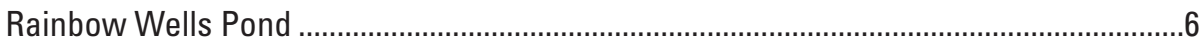

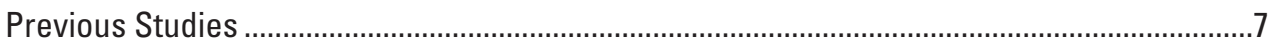

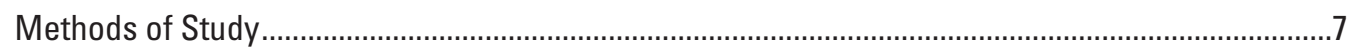

Sample Collection and Processing ..........................................................................................

Water-Quality Samples and Measurements ..................................................................

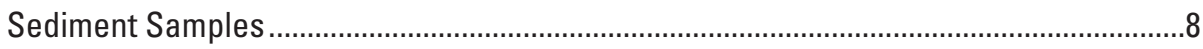

Continuous Temperature Monitoring.........................................................................

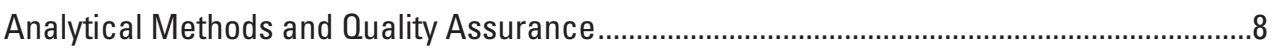

Biotic Ligand Model....................................................................................................... 11

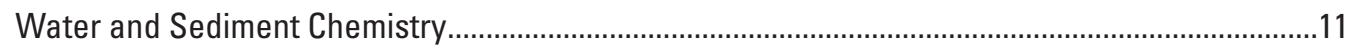

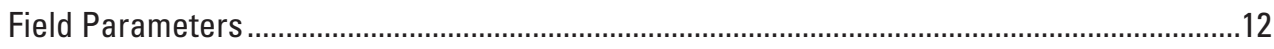

Continuous Temperature ........................................................................................... 19

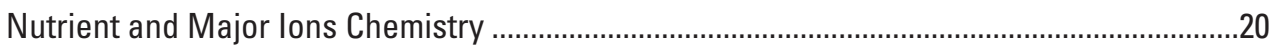

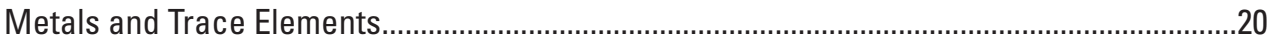

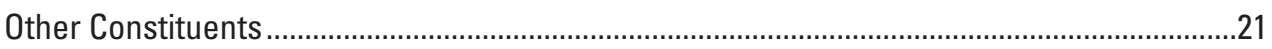

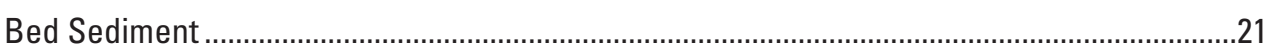

Suitability of Potential Habitats: Rainbow Wells Pond and West Pond............................................22

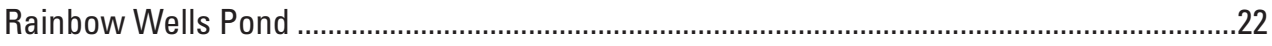

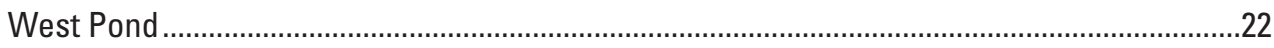

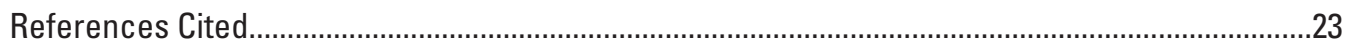

\section{Figures}

1. Map showing location of select monitoring sites in Mojave National Preserve and other existing Mohave tui chub populations in the Mojave Desert, California, 2018

2. Aerial image showing Mohave tui chub habitats at Zzyzx, Mojave National Preserve, California, 2018

3. Photograph showing sublocations for water and sediment sampling at Rainbow Wells Pond, Mojave National Preserve, California, 2018.

4. Graph showing continuous water temperature in Rainbow Wells Pond and West Pond, Mojave National Preserve, California, February-November 2018 


\section{Tables}

1. Station identification and location of potential and existing suitable habitats for the introduction of Mohave tui chub in the Mojave National Preserve, California, 2018

2. Field measurement and major ion quality-control sample results for Rainbow Wells Pond and Lake Tuendae, Mojave National Preserve, California, February-November 2018

3. Nutrient quality-control sample results from West Pond and Rainbow Wells Pond, Mojave National Preserve, California, February-March 2018.

4. Field parameter measurements of water at five existing and potential Mohave tui chub habitats within Mojave National Preserve, California, FebruaryNovember 2018.

5. Nutrient concentrations in water samples from five potential and existing Mohave tui chub habitats in Mojave National Preserve, California, FebruaryNovember 2018

6. Major ion and trace metal concentrations in water from five potential and existing Mohave tui chub habitats in Mojave National Preserve, California, February-November 2018

7. Aqueous metal and trace element concentrations for Rainbow Wells Pond and Morning Star Mine, Mojave National Preserve, California, March-November 2018 .....15

8. Observed data for Rainbow Wells Pond used as input to the Biotic Ligand Model for calculating acute and chronic copper concentrations, Mojave National Preserve, California, March-November 2018.

9. Calculated criterion maximum concentration and criterion continuous concentration values determined by using the U.S. Environmental Protection Agency's Biotic Ligand Model for observed copper concentrations in water samples from Rainbow Wells Pond, Mojave National Preserve, California, March-November 2018

10. Volatile organic compound concentrations in water from Rainbow Wells Pond, Mojave National Preserve, California, August 21, 2018.

11. Metal concentrations in bed-sediment samples from Rainbow Wells Pond, Mojave National Preserve, California, May-August 2018.

\section{Conversion Factors}

\begin{tabular}{lcl}
\hline \multicolumn{1}{c}{ Multiply } & By & To obtain \\
\hline & Length & \\
\hline centimeter $(\mathrm{cm})$ & 0.3937 & inch (in.) \\
millimeter $(\mathrm{mm})$ & 0.03937 & inch (in.) \\
meter $(\mathrm{m})$ & 3.281 & foot (ft) \\
\hline \multicolumn{3}{c}{ Mass } \\
\hline gram $(\mathrm{g})$ & 0.03527 & ounce, avoirdupois (oz) \\
kilogram $(\mathrm{kg})$ & 2.205 & pound avoirdupois (lb) \\
\hline
\end{tabular}

Temperature in degrees Fahrenheit $\left({ }^{\circ} \mathrm{F}\right)$ may be converted to degrees Celsius $\left({ }^{\circ} \mathrm{C}\right)$ as ${ }^{\circ} \mathrm{C}=\left({ }^{\circ} \mathrm{F}-32\right) / 1.8$. 


\section{Datum}

Horizontal coordinate information is referenced to the North American Datum of 1983 (NAD 83).

Elevation, as used in this report, refers to distance above the vertical datum.

\section{Supplemental Information}

Specific conductance is given in microsiemens per centimeter at 25 degrees Celsius $\left(\mu \mathrm{S} / \mathrm{cm}\right.$ at $\left.25^{\circ} \mathrm{C}\right)$.

Concentrations of chemical constituents in water are given in either milligrams per liter (mg/L) or micrograms per liter $(\mu \mathrm{g} / \mathrm{L})$.

\section{Abbreviations}

$\begin{array}{ll}\text { CCC } & \text { criterion continuous concentrations } \\ \text { CMC } & \text { criterion maximum concentration } \\ \text { DOC } & \text { dissolved organic carbon } \\ \text { EPA } & \text { U.S. Environmental Protection Agency } \\ \text { NPS } & \text { U.S. National Park Service } \\ \text { PEC } & \text { probable-effect concentrations } \\ \text { TDS } & \text { total dissolved solids } \\ \text { USFWS } & \text { U.S. Fish and Wildlife Service } \\ \text { USGS } & \text { U.S. Geological Survey } \\ \text { VOC } & \text { volatile organic compound }\end{array}$





\title{
Water and Sediment Chemistry of Selected Existing and Potential Habitats of the Mohave Tui Chub, Mojave National Preserve, California, 2018
}

\author{
By Katherine J. Earp and Angela P. Paul
}

\section{Abstract}

The Mohave tui chub (Siphateles bicolor mohavensis) was nearly extirpated from the Mojave River drainage in California by the mid-twentieth century and was listed as endangered in 1970. A source population of Mohave tui chub exists at MC Spring in Zzyzx, California, and has been used for several re-establishment efforts in previous decades. Two potential habitats in the Mojave National Preserve with perennial sources of water were identified by the National Park Service as candidates for additional Mohave tui chub re-establishment: West Pond and Rainbow Wells Pond. West Pond, an artificial pond at Zzyzx near MC Spring, contained a population of Mohave tui chub that died off in 1985 because of changes in water quality. The pond was rehabilitated in the past several years through re-excavation and by pumping fresh groundwater into the pond. Rainbow Wells Pond is an abandoned excavated mine site in the Cima Dome area. The bottom of the excavation intersects the water table, forming a pond. In cooperation with the National Park Service, the U.S. Geological Survey monitored water-quality conditions at West Pond and Rainbow Wells Pond for 1 year to characterize the suitability of spring habitat for re-establishment of Mohave tui chub populations. Data were also collected at three existing Mohave tui chub habitats in Mojave National Preserve to provide further information on the range of acceptable physical and chemical conditions. Initial water-quality results at West Pond indicate the pond has similar water quality as existing Mohave tui chub habitats. Initial water-quality results at Rainbow Wells Pond indicate the dissolved oxygen concentrations and springtime water temperatures are less than the long-term tolerable ranges for Mohave tui chub.

\section{Introduction}

The Mohave tui chub (Siphateles bicolor mohavensis) is a member of the minnow family (Cyprinidae) endemic to the Mojave River in California. The Mohave tui chub was extirpated from the Mojave River because of habitat degradation as well as hybridization and competition with the arroyo chub (Gila orcuttii), which was introduced as a bait fish in the 1930s (Hubbs and Miller, 1943). The Mohave tui chub was listed as endangered by the U.S. Fish and Wildlife Service (USFWS) in 1970, and a recovery plan was developed in 1984 (U.S. Fish and Wildlife Service, 1984).

According to the recovery plan, the Mohave tui chub can be delisted once it is re-established in the majority of its historical habitat in the Mojave River. This outcome is currently unattainable because of the continued presence of introduced fish species and changes in habitat (U.S. Fish and Wildlife Service, 1984; Lovich and Meyer, 2002). The interim objective of the recovery plan is to downlist the Mohave tui chub from the "endangered" status to "threatened" after six independent populations are established near the broader Mojave River drainage. As of 2021, five Mohave tui chub populations met the criteria of the recovery plan: Lark Seep at China Lake Naval Weapons Center (established 1972); Camp Cady Wildlife Area (established 1986); Lewis Center for Educational Research in Apple Valley (established 2008); Morning Star Mine pit lake in Mojave National Preserve (established 2011); and MC Spring and Lake Tuendae, which contain two subpopulations of a single population at Zzyzx, the NPS-administered housing unit and research center in Mojave National Preserve (figs. 1, 2). At the time the recovery plan was drafted (1984), a third subpopulation existed at Zzyzx, in West Pond; however, the West Pond Mohave tui chub population died off in 1985 as a result of changes in water quality (U.S. Fish and Wildlife Service, 2009).

Re-establishing a third subpopulation at Zzyzx and establishing a new population within the Mojave River drainage are among the downlisting requirements in the recovery plan. The plan lists 14 attempts to establish new populations in the Mojave River drainage area between 1939 and 1981, only one of which, Lark Seep at China Lake Naval Weapons Center, is still extant as of 2021 (U.S. Fish and Wildlife Service, 1984; fig. 1). Inadequate water quality, limited water quantity, and floods are considered the primary reasons for the large number of failures to establish new populations in the Mojave River drainage (U.S. Fish and Wildlife Service, 1984). Introducing Mohave tui chub to new habitats without a careful water-quality assessment could 


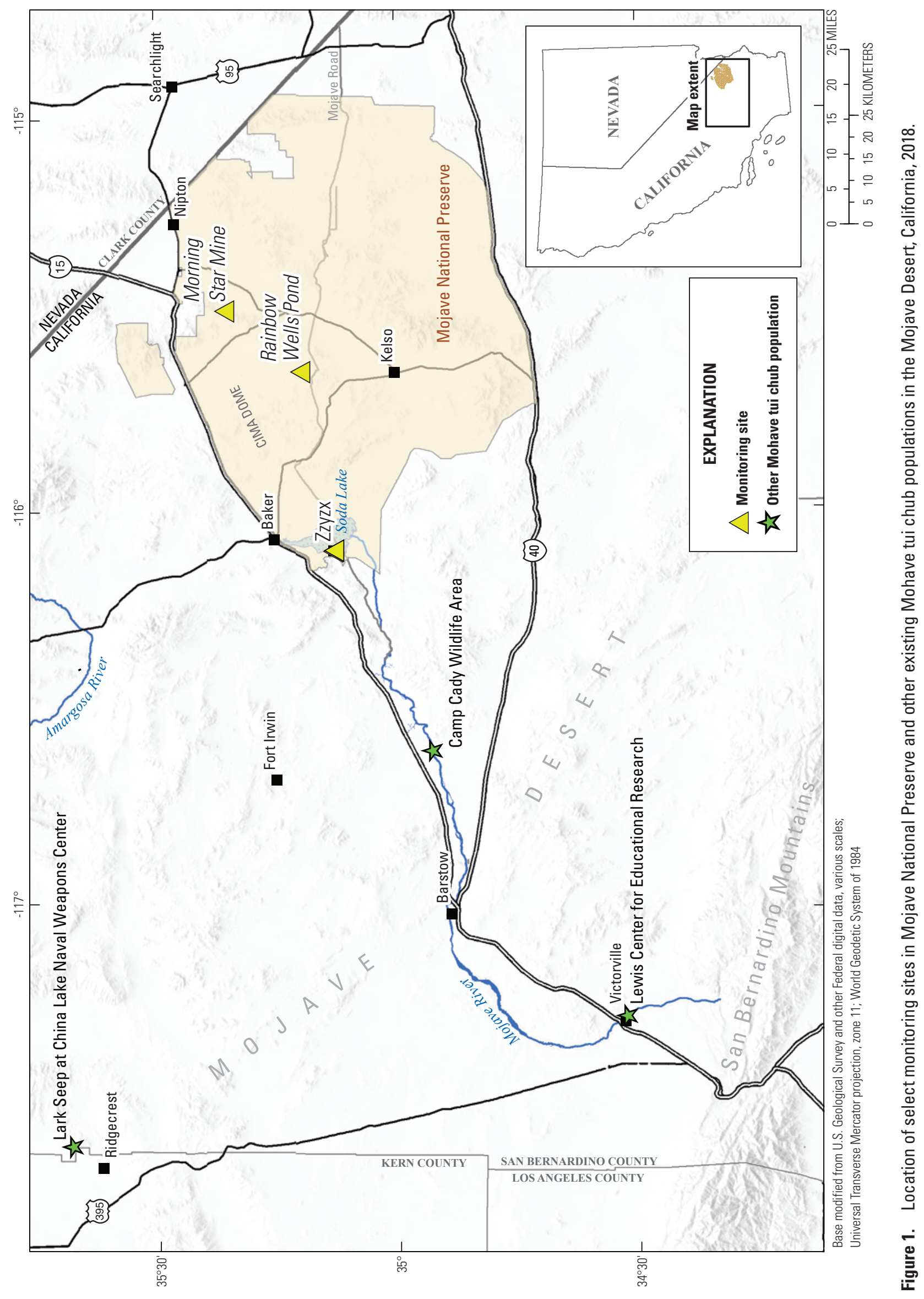




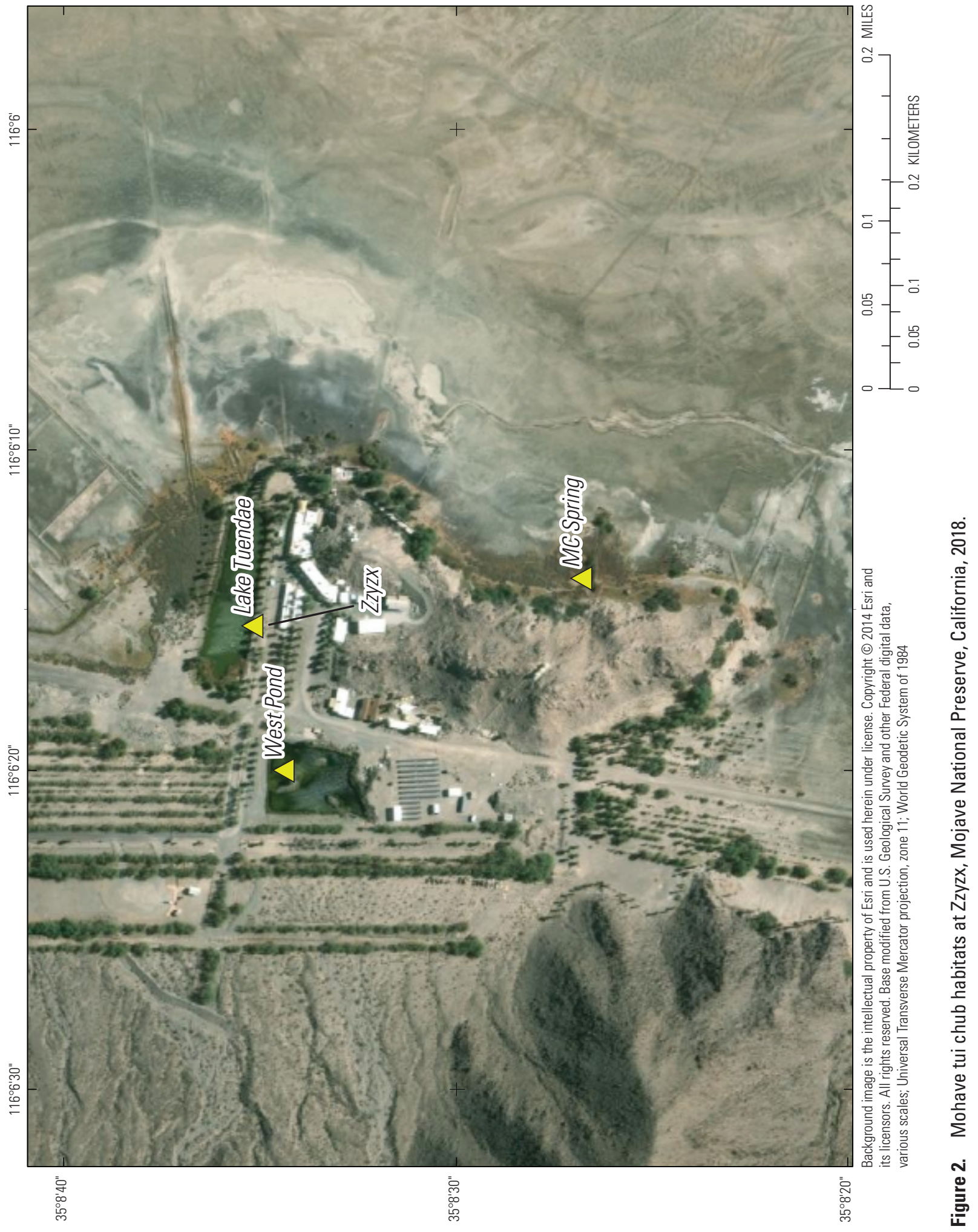


result in the failure of those populations, which would deplete the limited resources available to support the Mohave tui chub's recovery and delay downlisting efforts.

Few aquatic environments in the Mojave River drainage can sustain a stable Mohave tui chub population because surface water in the area is limited primarily to ephemeral flows (U.S. Fish and Wildlife Service, 2009). The U.S. National Park Service (NPS) has been heavily involved in the Mohave tui chub recovery effort since the establishment of Mojave National Preserve in 1994. Two potential refugia in Mojave National Preserve that have perennial sources of water have been identified by the NPS as candidates for Mohave tui chub re-establishment in the preserve: Rainbow Wells Pond and West Pond (Desert Fish Habitat Partnership, 2016).

\section{Purpose and Scope}

In cooperation with the NPS, the U.S. Geological Survey (USGS) characterized the water-quality conditions at Rainbow Wells Pond and West Pond for 1 year to evaluate the suitability for Mohave tui chub introduction. With suitable water-quality conditions, the NPS plans to establish Mohave tui chub at Rainbow Wells Pond and West Pond to meet one of the required conditions for downlisting populations to "threatened" status.

This report documents the methods and results of a basic water-quality evaluation of two proposed habitats at Rainbow Wells Pond and West Pond and of a sediment-chemistry evaluation for Rainbow Wells Pond. In addition, similar documentation of the water-quality characteristics at three established habitats of the Mohave tui chub is provided as further information about the range of acceptable conditions: MC Spring, Lake Tuendae, and Morning Star Mine (table 1). Water quality was documented through discrete quarterly sampling of field water-quality parameters, nutrients, major ions, and selected trace elements. Water temperature was continuously monitored at Rainbow Wells Pond and West Pond. Additional discrete samples were collected for dissolved organic carbon (DOC), volatile organic compounds (VOCs), and sediment chemistry at Rainbow Wells Pond.
Water quality of the two proposed ponds was compared to the existing Mohave tui chub habitats, U.S. Environmental Protection Agency (EPA) screening levels, and published tolerances in the scientific literature to determine whether water-quality conditions at the proposed sites are suitable for Mohave tui chub introduction.

\section{Description of Study Area}

The Mohave tui chub is endemic to the Mojave River, which originates in the San Bernardino Mountains and flows northeasterly for about 100 miles to the river terminus at Soda Lake (fig. 1). The river is a remnant of a Pleistocene river that flowed to ancient lakes, including Lakes Mojave and Manix (Stoffer, 2004), and much of the channel is dry.

Mojave National Preserve is in southeastern California within the greater Mojave Desert ecosystem, and parts of the preserve lie within the Mojave River drainage. Although the preserve receives between 10 centimeters $(\mathrm{cm})$ of precipitation per year in lower elevations and $30 \mathrm{~cm}$ per year in higher elevations, the only natural surface-water bodies in the preserve are 240 seeps and springs (National Park Service, 2018). Many of these seeps and springs go dry in years of drought. Human-created water bodies include ornamental ponds, stock tanks, and former mining pits.

Although additional potential Mohave tui chub habitats have been identified throughout the Mojave River drainage basin, the NPS is obligated by their Management Plan for Developed Water Resources to maintain habitat and pursue additional sites for the Mohave tui chub (National Park Service, 2018). Current habitat in Mojave National Preserve includes the MC Spring and Lake Tuendae populations at Zzyzx and the population at Morning Star Mine (figs. 1 and 2). Proposed locations for Mohave tui chub introduction include West Pond and Rainbow Wells Pond.

Table 1. Station identification and location of potential and existing suitable habitats for the introduction of Mohave tui chub in the Mojave National Preserve, California, 2018.

[Latitude and longitude coordinate symbols: ${ }^{\circ}$, degrees; ', minutes; ", seconds. Coordinates are referenced to North American Datum of 1983 and elevation is referenced to North American Vertical Datum of 1988]

\begin{tabular}{|c|c|c|c|}
\hline $\begin{array}{c}\text { Station identification } \\
\text { number }\end{array}$ & Station name & Coordinates & $\begin{array}{c}\text { Elevation } \\
\text { (feet) }\end{array}$ \\
\hline 350827116061401 & MC Spring & Latitude $35^{\circ} 08^{\prime} 26.8^{\prime \prime}$, Longitude $116^{\circ} 06^{\prime} 14.0^{\prime \prime}$ & 960 \\
\hline 350835116061501 & Lake Tuendae & Latitude $35^{\circ} 08^{\prime} 35.2^{\prime \prime}$, Longitude $116^{\circ} 06^{\prime} 15.5^{\prime \prime}$ & 960 \\
\hline 351218115385901 & Rainbow Wells Pond & Latitude $35^{\circ} 12^{\prime} 18.3^{\prime \prime}$, Longitude $115^{\circ} 38^{\prime} 58.5^{\prime \prime}$ & 4,475 \\
\hline
\end{tabular}




\section{Zzyzx}

The springs at Zzyzx, California, are a collection of one natural spring (MC Spring) and two excavated ponds (Lake Tuendae and West Pond; fig. 2). The springs, near the edge of Soda Lake, were part of the traditional territory of the Chemehuevi and Mohave native peoples prior to the arrival of the Spanish (Cultural Systems Research, Inc., 2002). The area was first developed by Anglo-Americans as a U.S. Army outpost in 1860 along the Mohave Road before briefly becoming a station along the Tonopah and Tidewater Railroad, which operated from 1907 to 1940 (Woo and Hughson, 2003). The USGS first characterized the springs in 1909 (Mendenhall, 1909). The area was federal property that was leased and developed by Curtis Howe Springer in 1944 as the Zzyzx Mineral Springs and Health Spa. The Bureau of Land Management resumed management of the federal property in 1974. In 1976, the California State University system entered into a cooperative agreement with the Bureau of Land Management to operate the Desert Studies Center (Desert Studies Center, 2019). The California Desert Protection Act of 1994 placed the Desert Studies Center in the newly created Mojave National Preserve, managed by the National Park Service.

\section{Spring}

MC Spring is a natural spring on the edge of Soda Lake, the terminus of the Mojave River. The spring head forms a pool that is 3 meters $(\mathrm{m})$ in diameter and $2 \mathrm{~m}$ deep with a channelized outlet that infiltrates the dry lakebed 50 $\mathrm{m}$ downstream. Regular removal of cattails is required to maintain the pond as an open-water fish habitat. (Bailard and Moret, 2015).

Mohave tui chub at MC Spring are likely either a relic population of the Mojave River and ancient Pleistocene lakes or were introduced prior to the 1930s by flooding of Soda Lake (fig. 1; U.S. Fish and Wildlife Service, 2009). The arroyo chub (Gila orcuttii) was introduced to the Mojave River headwaters in the San Bernardino mountains as a sportfish in the 1930s, and after widespread flooding in 1938, entered the lower Mojave River drainage and quickly hybridized with the Mohave tui chub (Hubbs and Miller, 1943). MC Spring was identified as an isolated population of genetically pure Mohave tui chub (U.S. Fish and Wildlife Service, 1984). MC Spring was used as a source population for several reintroduction efforts until low genetic diversity was identified in the spring population (U.S. Fish and Wildlife Service, 2009).

\section{Lake Tuendae}

Lake Tuendae, $275 \mathrm{~m}$ north of MC Springs, was excavated in 1955 as a 30-by-50-m artificial pond during the time the Zzyzx Mineral Springs and Health Resort was in operation (Woo and Hughson, 2003). During that time, the pond was stocked with Mohave tui chub, presumably sourced from MC Spring. Lake water levels are maintained by pumping water from a nearby well to a fountain in the middle of the lake. Periodic dredging is needed to clear the lake of cattails and silt to maintain habitat for the Mohave tui chub. Although the parasitic Asian Tapeworm Bothriocephalus acheilognathi was found in the Mohave tui chub in Lake Tuendae in 2001, subsequent studies indicated that the tapeworm has a negligible effect on the fish population (Archdeacon, 2007). Lake Tuendae has been used as a source population of Mohave tui chub for restocking efforts in other ponds because of its robust population and relatively high genetic variability (Henkanaththegedara, 2012).

\section{West Pond}

West Pond (also known as Three Bats Pond) is 75 $\mathrm{m}$ southwest of Lake Tuendae. The pond is a roughly 50-by-70-m rectangle, averages less than $1 \mathrm{~m}$ deep, and has three small islands. West Pond is believed to have been excavated sometime between 1944 and 1974 as an ornamental pond and subsequently stocked with Mohave tui chub. After acquisition of the pond in 1974, the Bureau of Land Management deepened and widened it in 1979, 1982, and 1992 to a maximum depth of $1.8 \mathrm{~m}$. The salinity in the pond has historically been high because of natural evaporation and recharge from the nearby leach field for the Zzyzx septic system (Desert Fish Habitat Partnership, 2016).

The initial Mohave tui chub population in West Pond died off in 1985; possible causes include increased ammonia toxicity and high salinity (Hughson and Woo, 2004). Several rehabilitation efforts have been attempted at the pond since the 1980 s, but until recently none were successful at permanently improving the water quality (Hughson and Woo, 2004). In 2016, the National Park Service began a restoration effort and pumped all the brackish water out of West Pond and filled it with groundwater pumped from a nearby well. Since 2016, the management plan for the site is to pump fresh water into the pond every other day to reduce the salinity and reverse the flow gradient from the leach field. The initial results of this management plan showed that water quality at West Pond was improved by the restoration activities and was comparable to Lake Tuendae, an existing Mohave tui chub habitat (Desert Fish Habitat Partnership, 2016). West Pond is considered by the NPS to have the highest potential within the boundaries of the preserve for reintroduction of Mohave tui chub (Hughson and Woo, 2004).

\section{Morning Star Mine}

Morning Star Mine is an abandoned open-pit gold mine near the northern end of Mojave National Preserve. The mine was active from 1907 to 1993, but pit excavation stopped in 1990 (Theodore, 2007). Groundwater seepage supplies the 1-acre pit with year-round water up to $9 \mathrm{~m}$ deep. Mohave tui chub were translocated to the pond in 2011 after biologists concluded that the site was suitable on the basis of its size, permanence, and water quality (U.S. Bureau of 
Reclamation, 2018). As of 2019, Morning Star Mine had a thriving population of Mohave tui chub. Morning Star Mine is considered a good control site for comparison with Rainbow Wells Pond because of similar mining histories.

\section{Rainbow Wells Pond}

Rainbow Wells Pond is a horseshoe-shaped feature in Mojave National Preserve near the top of Cima Dome, a granite pluton (figs. 1, 3). The site was created using a bulldozer as a prospect pit during the late 1980s. The bottom of the excavation intersects a shallow water table 3-3.5 $\mathrm{m}$ below ground surface, forming a pond with presumed perennial inflow. The pond is fed by occasional precipitation and a local perched aquifer (Desert Fish Habitat Partnership, 2016). The water-surface area of the pond fluctuates from an autumnal low of approximately $15-b y-6 \mathrm{~m}$ to a late winter high of 60 -by- $15 \mathrm{~m}$. The pond is dominated by cattails, which cover approximately three-quarters of the pond surface area. Minimum depth of water in the pond has been observed to be as low as $0.6 \mathrm{~m}$ during dry years. The depth of water in the pond varies seasonally and was at its lowest stages in 2012, 2014, and 2015. During the lowest stage in 2014-15, the cattail-free area of the pond was measured at approximately 2-by-3 $\mathrm{m}$ and was $1.2 \mathrm{~m}$ deep in the center. A large desert willow tree grows next to the pond, shading much of the open water throughout the day. Rainbow Wells Pond has been visited regularly by the NPS from 2012 to present. Rainbow Wells Pond is considered by the NPS to have the second-highest potential for reintroduction of Mohave tui chub within the boundaries of the preserve, second only to West Pond (Desert Fish Habitat Partnership, 2016).

When the mining claim at the Rainbow Wells Pond site became inactive in the 1990s, several small buildings and a mill site were abandoned, and the site was briefly used to manufacture illegal drugs in 1998. Mojave National Preserve hired a contractor to undertake a site cleanup, environmental assessment, and building removal during 1998 and 1999. More than thirty 55-gallon drums of hazardous materials were removed from the site, including "flammable liquids, paints, poisons, corrosive solids, several types of acids, ammonia, cyanide, batteries, and oily substances" (Desert Fish Habitat Partnership, 2016). As of 2018, abandoned metal-mining equipment remained in the pond. A soil sample collected from the site in 1999 had a lead concentration of 3,800 milligrams per kilogram $(\mathrm{mg} / \mathrm{kg})$ and a mercury concentration of 2,800 micrograms per kilogram $(\mu \mathrm{g} / \mathrm{kg})$. Both metal concentrations exceed the relevant EPA standards for protection of human health and were indicative of contamination. A sample of pond sediment collected at the same time had a mercury concentration of $420 \mu \mathrm{g} / \mathrm{kg}$, exceeding the EPA's Region 5 ecological screening level of $174 \mu \mathrm{g} / \mathrm{kg}$ (Desert Fish Habitat Partnership, 2016; fig. 3). Cyanide was also detected in sediment from the pond.

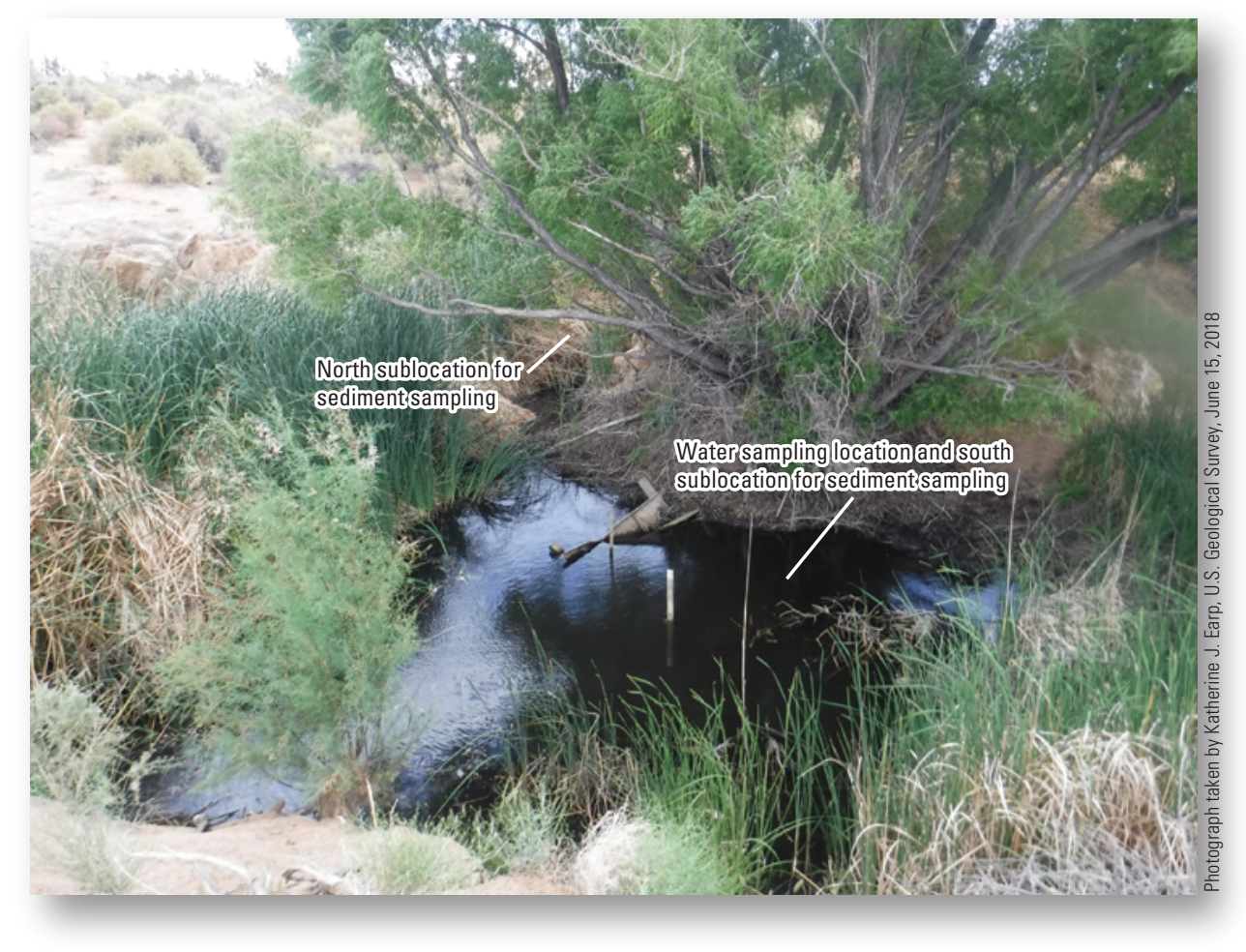

Figure 3. Sublocations for water and sediment sampling at Rainbow Wells Pond, Mojave National Preserve, California, 2018. 


\section{Previous Studies}

Several studies have been completed for the Zzyzx springs, mostly related to Mohave tui chub physiology and genetics. Mohave tui chub were first identified in the Mojave River in 1918 by John Snyder (Snyder, 1918), and the first major report on the species was completed by Robert Miller (1936). Hubbs and Miller (1943) further identified and characterized hybridization between the Mohave tui chub and the arroyo chub, which provided the foundation for genetic research on the fish that continues to the present (Chen and others, 2012). Nomenclature reclassification for the Mohave tui chub from the genus Gila to Siphateles was based on work by Simons and Mayden (1999). Habitat preferences were first described by Vickers (1973) and further characterized by Archbold (1996). Threats to the Mohave tui chub, including the Asiatic tapeworm Bothriocephalus acheilognathi and the invasive western mosquitofish Gambusia affinis, have been studied by Archdeacon (2007) and Henkanaththegedara (2012), respectively. Several studies have tried to determine the source of water to the springs (T. Bilhorn and C.R. Feldmeth, Bureau of Land Management, written commun., 1985; Barthel, 2008), but the results have been inconclusive. From 2014 to 2016, samples from West Pond and Lake Tuendae were collected by the NPS and Desert Studies Center staff to characterize the water chemistries (Desert Fish Habitat Partnership, 2016). Samples were taken before and after restoration at West Pond in December 2015. Alkalinity, bicarbonate, carbonate, chloride, specific conductance, fluoride, sulfate, total dissolved solids, potassium, and sodium all decreased by $81-98$ percent from pre-restoration levels. In comparison, after restoration of West Pond, relative differences between West Pond and Lake Tuendae field parameter and major ion concentrations averaged only 10 percent, indicating that the two habitats were similar in water quality.

All studies pertaining to Rainbow Wells Pond have been performed or commissioned by the NPS. In 2015, approximately 20 invasive tamarisk trees were removed from the site to improve potential habitat for the Mohave tui chub. Fully restoring the site would require the removal of scrap metal from the mining operation discarded in the pond and the removal of extensive cattails and dead vegetation (National Park Service, 2015). In the winter of 2015-16, the NPS collected baseline water and sediment samples for laboratory analysis of general water chemistry, ammonia, phosphorus, and sulfide to identify elevated concentrations and assess potential negative effects to fish (Desert Fish Habitat Partnership, 2016). In the water samples, aluminum, at 250 milligrams per liter $(\mathrm{mg} / \mathrm{L})$, and iron, at 1,100 and 1,700 micrograms per liter $(\mu \mathrm{g} / \mathrm{L})$, exceeded the EPA chronic exposure standards for protection of aquatic life (U.S.

Environmental Protection Agency, 1986, 2018). The water samples collected in 2015-16 exceeded the 1988 EPA criterion for aluminum of $87 \mu \mathrm{g} / \mathrm{L}$, but it could not be determined if the samples exceeded the revised 2018 aluminum criterion. The 2018 EPA criterion for aluminum varies as a function of a site's $\mathrm{pH}$, total hardness, and dissolved organic carbon content, but hardness and DOC content were not measured in 2015-16. Some other contaminants of interest, such as ammonia and sulfide, were below detection-limit concentrations, but total phosphorus concentration $(0.29-0.34 \mathrm{mg} / \mathrm{L})$ was above the $0.017 \mathrm{mg} / \mathrm{L}$ criterion for EPA Aggregate Ecoregion III (U.S. Environmental Protection Agency, 2001; Desert Fish Habitat Partnership, 2016). In one of the two sediment samples, consensus-based freshwater sediment-quality guidelines (sediment guidelines) were exceeded for copper and mercury concentrations (Ingersoll and others, 2000). The results of the NPS investigation indicated the water and sediment at Rainbow Wells Pond were still contaminated by metals.

In addition to the known metals contamination, the NPS personnel visiting Rainbow Wells Pond have observed a strong hydrogen sulfide $\left(\mathrm{H}_{2} \mathrm{~S}\right)$ odor (Desert Fish Habitat Partnership, 2016). No hydrogen sulfide was detected in samples sent to the laboratory, although hydrogen sulfide measurements are most accurate when analyzed immediately after the sample is collected (Hach, 2009).

\section{Methods of Study}

Data collection for this study consisted of discrete water-quality samples, continuous monitoring of temperature, and discrete monitoring of field parameters. Gage heights were recorded by directly reading NPS-installed staff gages at MC Spring, West Pond, and Rainbow Wells Pond; no staff gages were available at Lake Tuendae or Morning Star Mine. A metal bioavailability model developed by the EPA was used to determine ecological criterion for aquatic copper concentration in Rainbow Wells Pond (U.S. Environmental Protection Agency, 2007). Sample quality was assured by collecting quality-control samples and by following USGS guidelines for the collection and publishing of discrete and continuous water-chemistry data (U.S. Geological Survey, variously dated; Wagner and others, 2006).

\section{Sample Collection and Processing}

Sampling frequency was designed to capture seasonal differences in water-quality data from February through November 2018. Discrete samples were collected quarterly from each of the five sites (MC Spring, Lake Tuendae, West Pond, Morning Star Mine, and Rainbow Wells Pond) from February 23, 2018, to November 28, 2018. Continuous temperature monitors were deployed at West Pond and Rainbow Wells Pond from February to November 2018.

\section{Water-Quality Samples and Measurements}

Water-quality field parameters were measured at all five sites during each sampling event and included temperature, $\mathrm{pH}$, specific conductance, and dissolved oxygen. 
All constituents were measured using either a YSI 6600 multiparameter sonde or OTT Hydrolab HL-7 multiparameter sonde, each calibrated using procedures according to manufacturer recommendations and the USGS National Field Manual (YSI, 2012; Hydrolab, 2019; U.S. Geological Survey, variously dated). The dissolved-oxygen sensor is accurate to $\pm 0.1 \mathrm{mg} / \mathrm{L}$ in the concentration range of 0 to $8 \mathrm{mg} / \mathrm{L}$ (Hydrolab, 2019). Physical parameters were measured either by wading into each pond or by deploying the sonde from the bank. Informal vertical profiles of field parameters were made at Morning Star Mine by deploying a multiparameter sonde from a boat and were made at Rainbow Wells Pond by wading with the multiparameter sonde. Both profiles indicated that the ponds were not stratified, which allowed for representative sampling from a shallow depth.

Water samples were collected and processed onsite using a peristaltic pump and plastic tubing using techniques described in the USGS National Field Manual (U.S. Geological Survey, variously dated). Masterflex tubing was typically deployed about 10 to 15 centimeters into the water column by using a float to sample water from the edge of the pond. Water samples were pumped from nearshore to a processing table on the edge of each pond.

Filtered water samples were collected for the analysis of nutrients, major ions, total dissolved solids, dissolved metals, and alkalinity. Filtered water samples collected from sites influenced by historical mining activities (Rainbow Wells Pond and Morning Star Mine) were also analyzed for additional trace elements. Unfiltered water samples were collected for the analysis of ammonia and organic nitrogen and phosphorus, a variety of volatile organic compounds, hydrogen sulfide, and cyanide. Hydrogen sulfide concentrations in water were analyzed in the field in February, August, and November using a Hach DR 900 Colorimeter following Hach Procedure No 8131, USEPA Methylene Blue Method (Hach, 2009). All water samples were shipped overnight to the USGS National Water Quality Laboratory (NWQL) in Lakewood, Colorado, for analysis.

In March 2018, unfiltered samples for total cyanide testing were collected at the sites affected by historical mining (Rainbow Wells Pond and Morning Star Mine). The cyanide samples were preserved with sodium hydroxide and sent to RTI Laboratories, Livonia, Michigan. Total cyanide is the term used to refer to the sum of all of the inorganic chemical forms of cyanide that dissociate when refluxed under strongly acidic conditions, whereas available cyanide refers to a group of cyanide species that undergo dissociation when refluxed under weakly acidic conditions (O.I. Analytical, 2009). Available cyanide was sampled at Rainbow Wells Pond in August 2018, because available cyanide has a lower detection limit $(2.0$ $\mu \mathrm{g} / \mathrm{L})$ than total cyanide $(10 \mu \mathrm{g} / \mathrm{L})$. Total cyanide (RTI Method: SM4500-CN-E) and available cyanide (RTI Method: ASTM-D6888) were analyzed using published methods (RTI Laboratories, 2019).

\section{Sediment Samples}

Bed-sediment samples were collected at Rainbow Wells Pond because previous work at this site indicated contamination from metals (Desert Fish Habitat Partnership, 2016). Samples were collected from two sublocations where runoff was expected to enter the pond (fig. 3). The northern pond sublocation is closest to the NPS sediment sample collected in 2016, where the greatest metal contamination was measured. The May 2018 sample was composited from the northern sublocation and a southern sublocation; the August 2018 samples were collected independently from each sublocation (not composited) so that the heterogeneity of the contamination could be evaluated. Each sample was collected from one location, taking care to collect only the top 1-10 $\mathrm{cm}$ of the sediment profile (collection method modified from Shelton and Capel, 1994). Sediment samples were sent to the NWQL for analysis of recoverable metals. Bed sediment was analyzed for aluminum, boron, cadmium, chromium, cobalt, copper, iron, lead, manganese, mercury, and zinc.

\section{Continuous Temperature Monitoring}

HOBO Tidbit ${ }^{\circledR}$ continuous temperature loggers were deployed at Rainbow Wells Pond and West Pond from February to November 2018. The logger at Rainbow Wells Pond was placed in the deepest part of the pond by using a cable attached to an anchor on the bank. The logger had to be relocated to deeper water several times during the study as the pond became drier. The West Pond logger was installed in a patch of reeds near the bank to protect the logger from direct sunlight. Water temperatures were logged every 15 minutes, and data were downloaded during each site visit. To verify select HOBO Tidbit ${ }^{\circledR}$ temperature measurements, discrete verification temperatures were collected using a multiparameter sonde calibrated against a National Institute of Standards and Technology-traceable thermometer. Continuous water-temperature records were analyzed and approved according to the USGS protocols for continuous water-quality data (U.S. Geological Survey, 2010).

\section{Analytical Methods and Quality Assurance}

Quality assurance for this study was maintained through standard USGS training of field personnel, use of standard USGS field protocols (U.S. Geological Survey, variously dated), collection of quality-control samples, use of USGS approved laboratories, and thorough review of all analytical results. Water and sediment samples were analyzed by the U.S. Geological National Water Quality Lab (NWQL) in Lakewood, Colorado, and by RTI Laboratories in Livonia, Michigan, under contract with the NWQL. Quality-control samples, including blanks and replicates, were collected at frequencies outlined in the USGS National Field Manual (U.S. Geological Survey, 2006). Measurements of temperature, 
specific conductance, dissolved oxygen, and $\mathrm{pH}$ were made in situ by trained USGS personnel. Laboratory measurements of $\mathrm{pH}$ were used in place of field measurements because of suspected probe malfunction on the multiparameter sonde. A single laboratory measurement of specific conductivity, 940 microsiemens per centimeter $(\mu \mathrm{S} / \mathrm{cm})$, was used in place of the field measurement of $1,440 \mu \mathrm{S} / \mathrm{cm}$ for the August sample collection at Rainbow Wells Pond. The field measurement was rejected because the field specific conductivity was 42 percent more than the lab measurement. All other reported specific conductivity values were field measurements (table 2).

With the exceptions of cyanide and alkalinity, all water samples were analyzed by the NWQL using standard measurement methods (ICP-MS, inductively coupled plasma-mass spectrometry; cICP-MS, collision cell inductively coupled plasma-mass spectrometry) for major ions and trace elements (Garbarino and others, 2006). Samples for cyanide were analyzed by RTI Laboratories in Livonia, Michigan. Alkalinities were analyzed while onsite or within 24 hours after collection at the USGS office in Henderson, Nevada.

Quality-control samples were collected to evaluate potential contamination, bias, and variability of the data that may have resulted from sample collection, processing, storage, transportation, or laboratory analysis. An equipment blank was processed before the initiation of sampling to ensure equipment and decontamination procedures were appropriate for study objectives. The equipment-blank sample for Rainbow Wells Pond on March 2, 2018, was analyzed for nutrients (table 3). Results were below detection except for Kjeldahl nitrogen (ammonia and organic nitrogen). The equipment-blank result for Kjeldahl nitrogen $(0.096 \mathrm{mg} / \mathrm{L})$ was 14 percent of the associated environmental sample result $(0.695 \mathrm{mg} / \mathrm{L})$ for Rainbow Wells Pond on March 3, 2018. This result is within USGS guidelines, which state that blank samples should not exceed 20 percent of the detected environmental sample (Mueller and others, 2015).

Field blank samples were prepared using certified blank water supplied by the USGS NWQL to verify that ambient conditions and sampling equipment did not introduce contamination to samples. A field blank for the West Pond was analyzed for nutrients (table 3), and field blanks for Rainbow Wells Pond and Lake Tuendae were analyzed for major ions (table 2). Blank samples generally had constituent concentrations that were less than laboratory reporting levels (tables $2-3$ ). In selected field blanks, chloride, silica, Kjeldahl nitrogen (ammonia and organic nitrogen), and nitrate plus nitrite nitrogen were measured at concentrations slightly greater than laboratory reporting levels. Concentrations of these constituents were less than 1 percent of concentrations in associated environmental samples. The May 23, 2018, field blank for Rainbow Wells Pond contained manganese at $0.436 \mathrm{mg} / \mathrm{L}$, which was more than twice the reporting limit of $0.2 \mathrm{mg} / \mathrm{L}$ but was less than 1 percent of the concentration in the associated environmental sample (table 2).

One replicate sample was collected on August 21,2018, at Rainbow Wells Pond to assess sample variability that could result from changing environmental conditions, sample collection, or processing procedures. Major ion concentrations in the replicate were compared to the associated environmental (regular) sample by calculating the relative percent difference between constituent concentrations in each sample. Relative percent differences were calculated using the following equation:

where

$$
\text { Relative Percent Difference }=\frac{\left|\left(C_{\text {replicate }}-C_{\text {regular }}\right)\right|}{\left(\frac{C_{\text {replicate }}+C_{\text {regular }}}{2}\right)} \times 100
$$

$C_{\text {replicate }}$ is the concentration measured in the replicate sample, and

$C_{\text {regular }}$ is the concentration measured in the regular (environmental) sample.

Relative percent differences ranged from about 0.5 to 5.0 percent for most constituents, indicating similar concentrations between the replicate and regular samples (table 2); however, iron concentrations showed a 23-percent difference. The larger percent relative difference in iron concentration could reflect the influence of the abandoned mining equipment in the pond.

Quality-control checks on all laboratory results for the environmental samples were generally acceptable, except for the phosphorus data. When filtered phosphorus and orthophosphorus data were compared to unspeciated (or total) data, filtered orthophosphorus concentrations were always less than unspeciated phosphorus. These differences fell outside what would be considered reasonable analytical variability. Relatively high silica concentrations were suspected as an analytical interferent with the orthophosphorus results (Sarah Stetson, U.S. Geological Survey, National Water Quality Laboratory, written communication, September 27, 2019). Orthophosphorus data were likely analytically biased, therefore were rejected and not reported here.

Continuous temperature data were reviewed using published (Wagner and others, 2006) and recommended USGS methods (U.S. Geological Survey, 2010). All time-series data were corrected using the AQUARIUS software (www.aquaticinfor matics.com) before being analyzed, approved, and audited according to USGS policy (U.S. Geological Survey, 2017). Approved continuous and discrete data were made publicly available as part of the National Water Information System (NWIS) database at https://waterdata.usgs.gov/nwis (U.S. Geological Survey, 2021). 


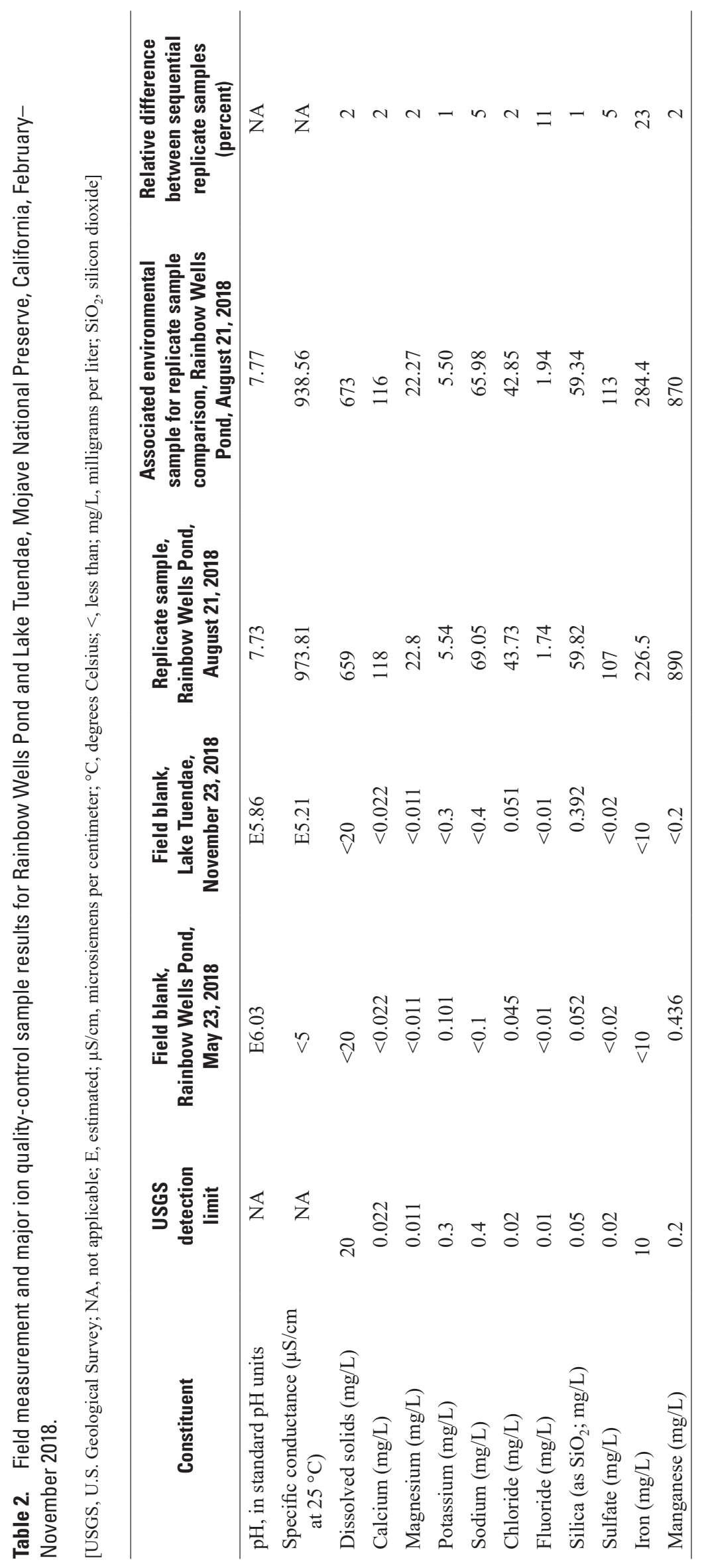


Table 3. Nutrient quality-control sample results from West Pond and Rainbow Wells Pond, Mojave National Preserve, California, February-March 2018.

[USGS, U.S. Geological Survey; mg/L, milligrams per liter; <, less than; - , no data]

\begin{tabular}{lccc}
\hline \multicolumn{1}{c}{ Constituent } & $\begin{array}{c}\text { USGS detection limit } \\
\text { (mg/L) }\end{array}$ & $\begin{array}{c}\text { Field blank, West Pond, } \\
\text { February 22, 2018 } \\
\text { (mg/L) }\end{array}$ & $\begin{array}{c}\text { Equipment blank, Rainbow Wells Pond, } \\
\text { March 1, 2018 } \\
\text { (mg/L) }\end{array}$ \\
\hline Ammonia & 0.01 & $<0.01$ & $<0.01$ \\
Ammonia and organic nitrogen & 0.07 & $<0.07$ & - \\
$\begin{array}{l}\text { Ammonia plus organic nitrogen (unfil- } \\
\quad \text { tered) }\end{array}$ & 0.07 & $<0.07$ & $<0.07$ \\
Nitrate plus nitrite & 0.04 & - & $<0.04$ \\
Nitrite & 0.001 & $<0.001$ & $<0.001$ \\
Orthophosphate & 0.004 & $<0.004$ & $<0.004$ \\
Phosphorus, unfiltered & 0.004 & 0.004 & $<0.004$ \\
Phosphorus & 0.003 & $<0.003$ & $<0.003$ \\
\hline
\end{tabular}

\section{Biotic Ligand Model}

In 2007, the EPA proposed the use of the Biotic Ligand Model to determine aquatic life criteria for copper (U.S. Environmental Protection Agency, 2016a). The model was designed to replace costly historical conservative approaches to establishing protective aquatic criteria by streamlining and integrating biologic and chemical information (Paquin and others, 2002; U.S. Environmental Protection Agency, 2007). Aquatic organisms regulate transfer of ions between their bodies and ambient water through specialized cells in the gill called ionocytes; the reduction of the ability to regulate ionic balance is the most detrimental effect of metals on aquatic organisms (Paquin and others, 2002; Hwang and others, 2011). The Biotic Ligand Model relates a toxicological response to predicted metal accumulation at sites of action (biotic ligands) in the gill and considers the association similar to what would be expected when evaluating the metal in water at a specific site (Paquin and others, 2002; U.S. Environmental Protection Agency, 2007). The model predicts the acute (criterion maximum concentrations, $\mathrm{CMC}$ ) and chronic (criterion continuous concentration, $\mathrm{CCC}$ ) aqueous copper concentrations that would be harmful to fish (U.S. Environmental Protection Agency, 2007). The Biotic Ligand Model was applied using site-specific water chemistry for Rainbow Wells Pond.

It has long been recognized that aqueous metal toxicity has been associated with the activity of metal ions in solution; the Biotic Ligand Model assumes the chemistry of the water is at equilibrium (Paquin and others, 2002). Dissolved organic carbon and water hardness are both known to mitigate metal toxicity (Pagenkopf, 1983; Parent and others, 1996; McGeer and others, 2002). Dissolved organic carbon complexes with metals, thereby rendering them biologically unavailable to aquatic organisms; hardness ions, such as calcium and magnesium, can compete with free metal ions in solution, thereby reducing the toxic effect of metals (Di Toro and others, 2001).

The Biotic Ligand Model requires the input variables water temperature; $\mathrm{pH}$; concentrations of alkalinity, calcium, chloride, copper, dissolved organic carbon, magnesium, potassium, sodium, and sulfate; and humic acid percentage (U.S. Environmental Protection Agency, 2016c). Although the U.S. Environmental Protection Agency (2016c) recommends using geostatistical modeling to estimate missing parameters, this was not done during this study. Disregarding the sample collected during the February-March sampling, for which DOC was not analyzed, humic acid was the only parameter for all samples collected as part of this study that was missing from the list of required input variables. The documentation for the model states that "the variability of the dissolved organic matter content in diverse water sources has not been found to be an especially critical parameter, and little benefit is achieved by characterizing natural organic matter beyond DOC concentrations." If DOC or humic acid concentrations are unspecified, a default value of 10 percent is recommended (Windward Environmental, 2017). A value of 10 percent was applied as the DOC content for the March 2, 2018, sample and as the humic acid content for all samples in the Biotic Ligand Model used in this study.

\section{Water and Sediment Chemistry}

The analytical results for the water-quality and sediment-chemistry samples collected seasonally at the study sites in Mojave National Preserve from February through November 2018 are presented in tables 4-11. These datasets are available online through the USGS National Water Information System (https://nwis.waterdata.usgs.gov; U.S. Geological Survey, 2021) by using the station-identification 
number given in table 1 . The detection limits have been determined for each constituent and are unique to each analytical method (U.S. Geological Survey, 2019). The water quality and sediment chemistry at Rainbow Wells Pond and the water quality at West Pond were compared to previously measured concentrations (Desert Fish Habitat Partnership, 2016), published tolerances specific to the Mohave tui chub (U.S. Fish and Wildlife Service, 2009), and EPA nationally recommended criteria for aquatic systems (U.S. Environmental Protection Agency, 2019). The EPA's national ambient water quality criteria for freshwater aquatic life protection are provided for selected constituents in tables 5, 7, and 9-11 (U.S. Environmental Protection Agency, 2019). Although most EPA aquatic criterion are national, nutrient criterion are based on state and regionally defined levels. The
Mojave National Preserve is a part of the EPA's Aggregate Ecoregion III, which is largely characterized by unforested landscapes used primarily as rangeland in a relatively dry climate (Omernik and Griffith, 2014).

\section{Field Parameters}

Discrete measurements of specific conductivity, $\mathrm{pH}$, and water temperature were taken during all field visits (table 4). Continuous water temperature (fig. 4) was measured between visits. Specific conductance in Rainbow Wells Pond (average of $1,000 \mu \mathrm{S} / \mathrm{cm}$ ) was considerably less than that observed in the four other locations in this study (average of 3,780 $\mu \mathrm{S}$ / $\mathrm{cm})$. The differences in specific conductance were likely due

Table 4. Field parameter measurements of water at five existing and potential Mohave tui chub habitats within Mojave National Preserve, California, February-November 2018.

$\left[\mathrm{mm} / \mathrm{dd} /\right.$ yyyy, month/day/year; ${ }^{\circ} \mathrm{C}$, degrees Celsius; $\mu \mathrm{S} / \mathrm{cm}$, microsiemens per centimeter; $\mathrm{CaCO}_{3}$, calcium carbonate; mg/L, milligrams per liter; —, no data $]$

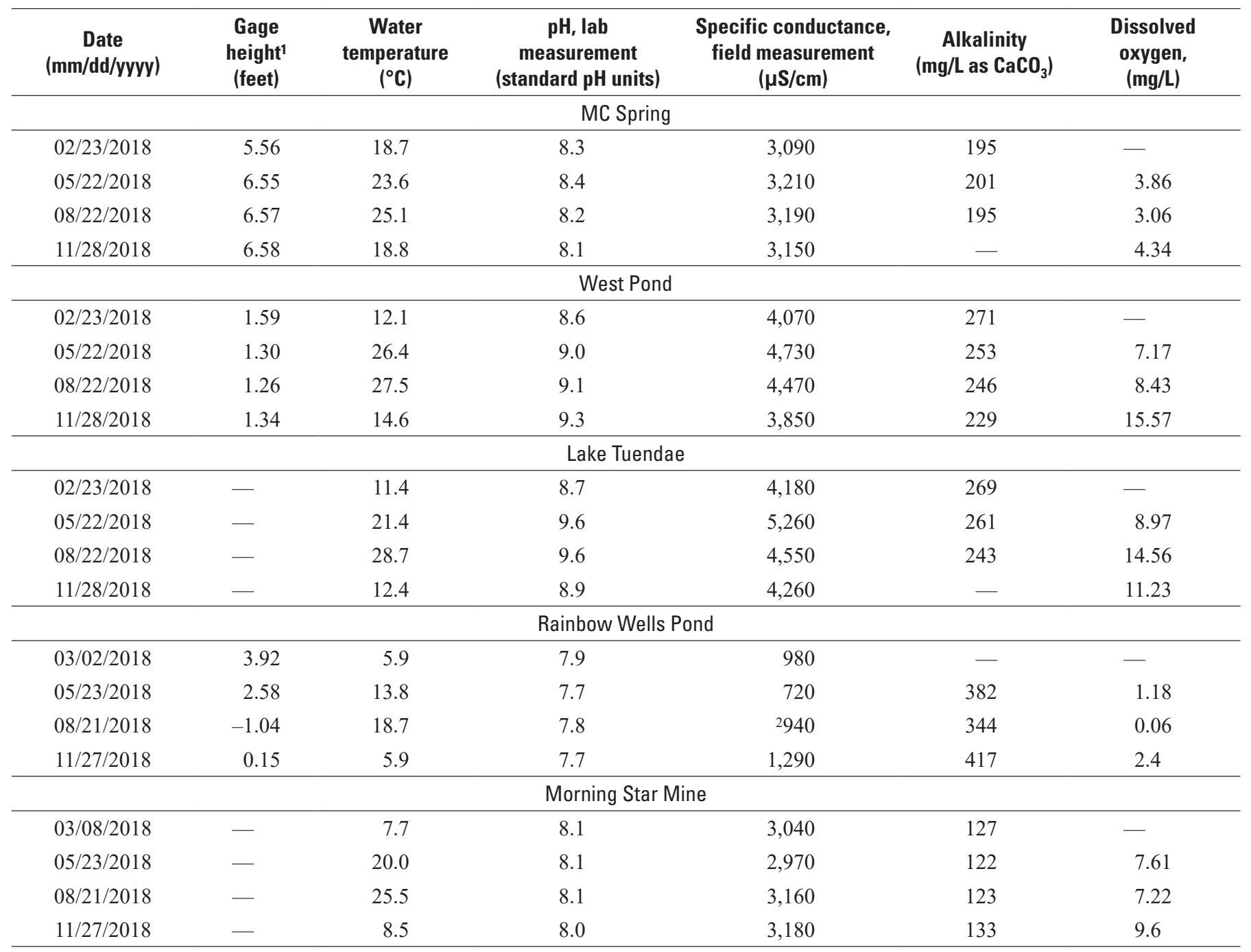

${ }^{1}$ Gage height is the elevation of the water surface above a reference point.

${ }^{2}$ Value was measured in laboratory. 
Table 5. Nutrient concentrations in water samples from five potential and existing Mohave tui chub habitats in Mojave National Preserve, California, February-November 2018.

[mm/dd/yyyy, month/day/year; mg/L, milligrams per liter; EPA, U.S. Environmental Protection Agency; —, no data; <, less than]

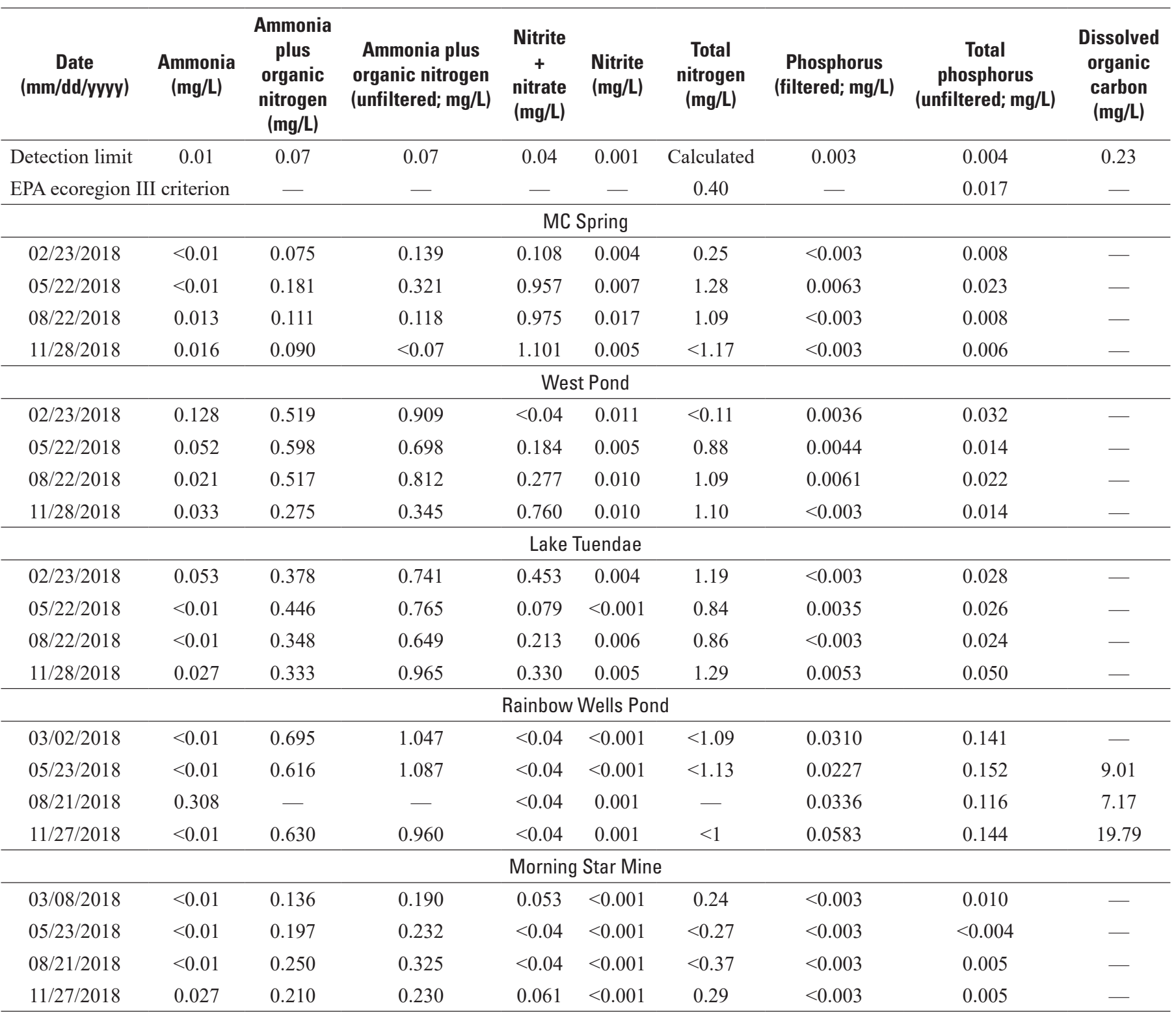

${ }^{1}$ Total nitrogen is the sum of total Kjeldahl nitrogen (unfiltered ammonia plus organic nitrogen) and nitrate-nitrite (Rus and others, 2012).

to source water, with the Zzyzx sites and Morning Star Mine reflecting groundwater with longer source-rock residence time and Rainbow Wells pond representing groundwater containing more recent precipitation. Values of specific conductance in Rainbow Wells Pond decreased between site visits on March $2(980 \mu \mathrm{S} / \mathrm{cm})$ and May 23, 2018 (720 $\mu \mathrm{S} / \mathrm{cm})$; after May, conductance increased to $1,290 \mu \mathrm{S} / \mathrm{cm}$. The increase in conductance between May and November was likely due to evaporation and concentration in the pond, indicating little or no additional water inflow during this period. The $\mathrm{pH}$ criterion for freshwater aquatic life is a range of 6.5-9.0; outside of this range, there is a gradual deterioration of the water quality because common pollutants can become more toxic (U.S. Environmental Protection Agency, 1986). For example, ammonia has been shown to be 10 times more toxic at $\mathrm{pH} 8.0$ than at $\mathrm{pH} 7.0$ (European Inland Fisheries Advisory Commission, 1969). Rainbow Wells Pond water is circumneutral $\mathrm{pH}$ (7.7-7.9); Morning Star Mine and MC Spring were at higher $\mathrm{pH}$ ranges (8.0-8.4) within the acceptable range for aquatic life; and Lake Tuendae and West Pond had multiple $\mathrm{pH}$ measurements (8.6-9.6) that were outside the acceptable aquatic $\mathrm{pH}$ range. 


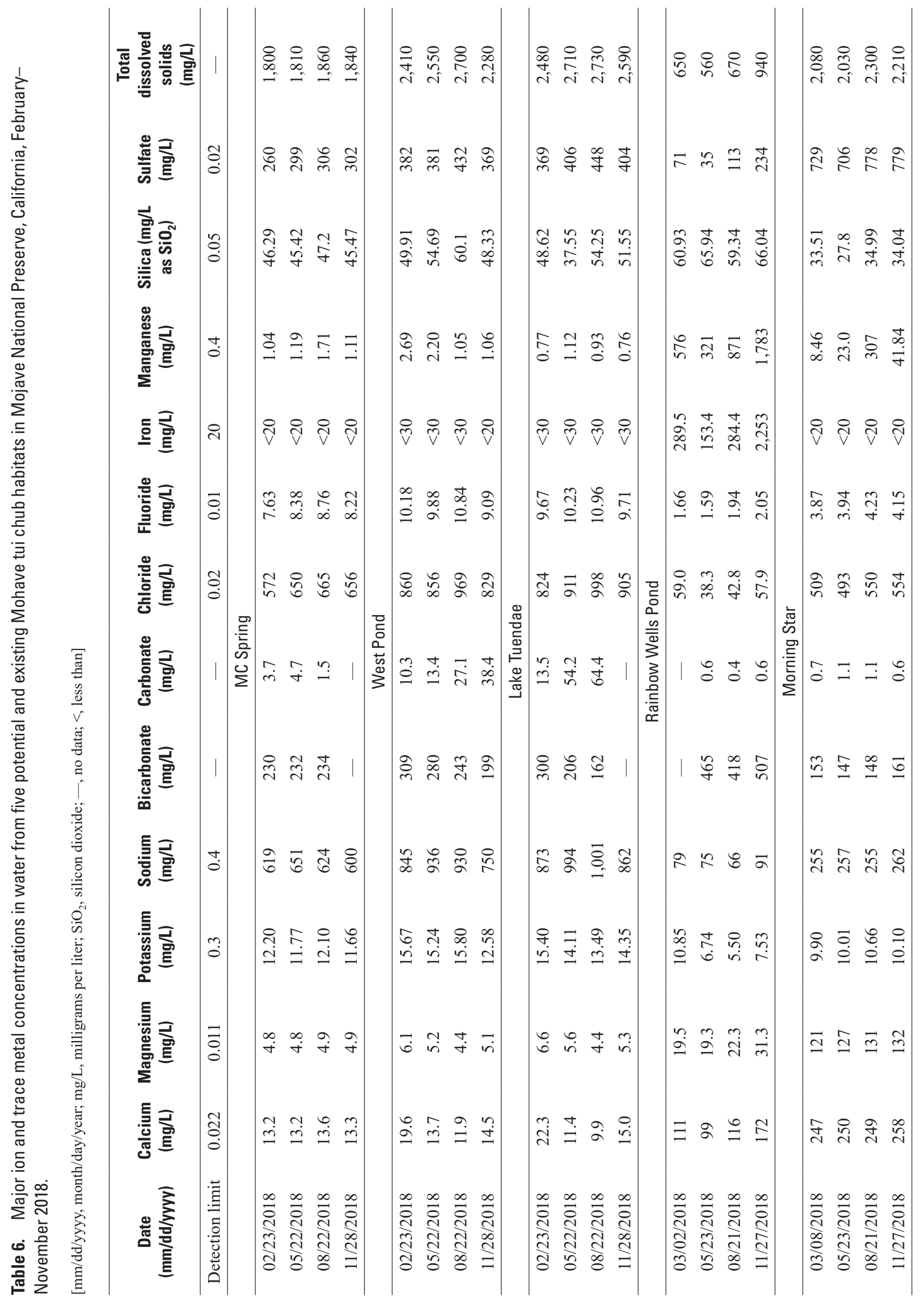




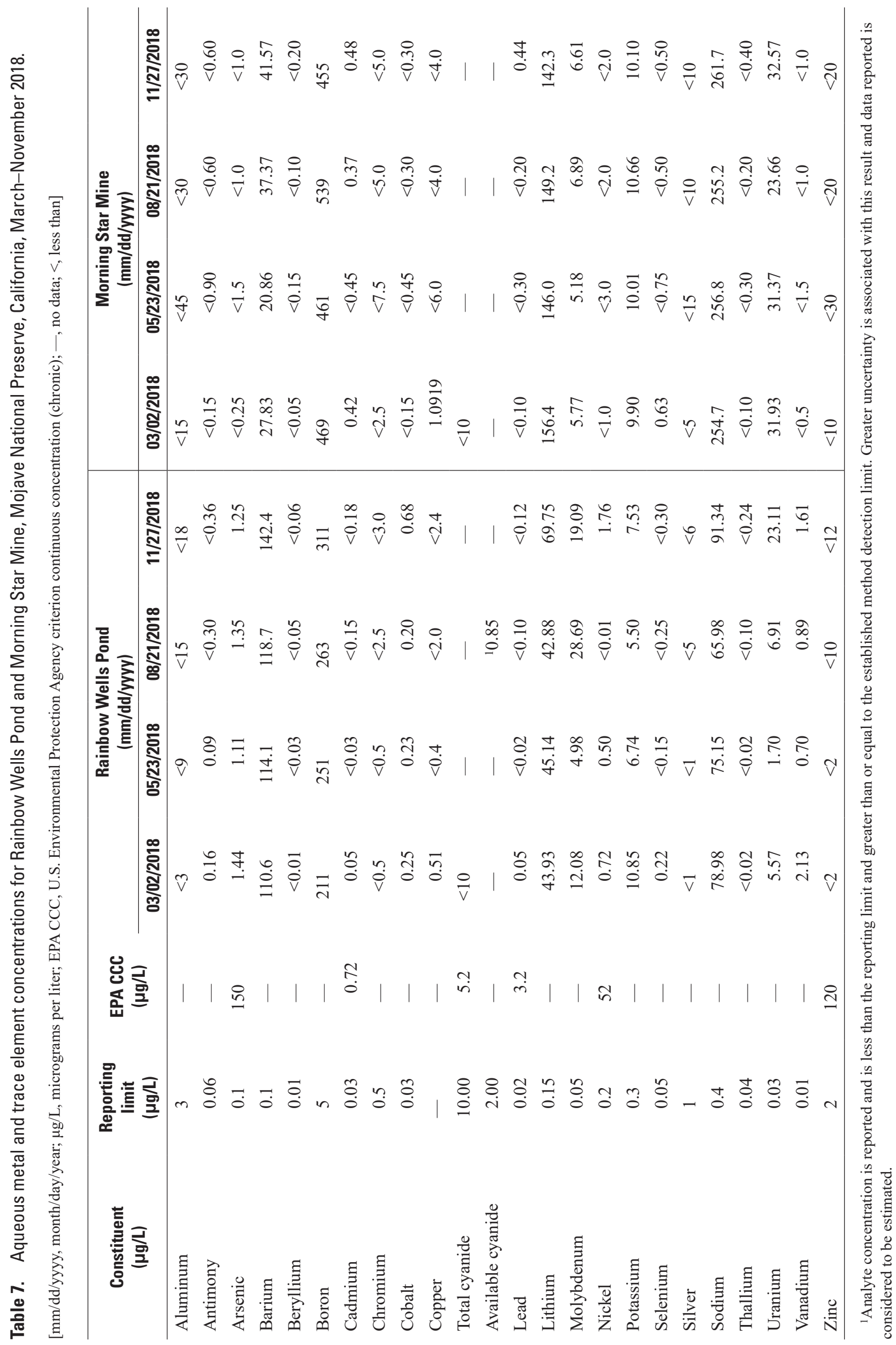




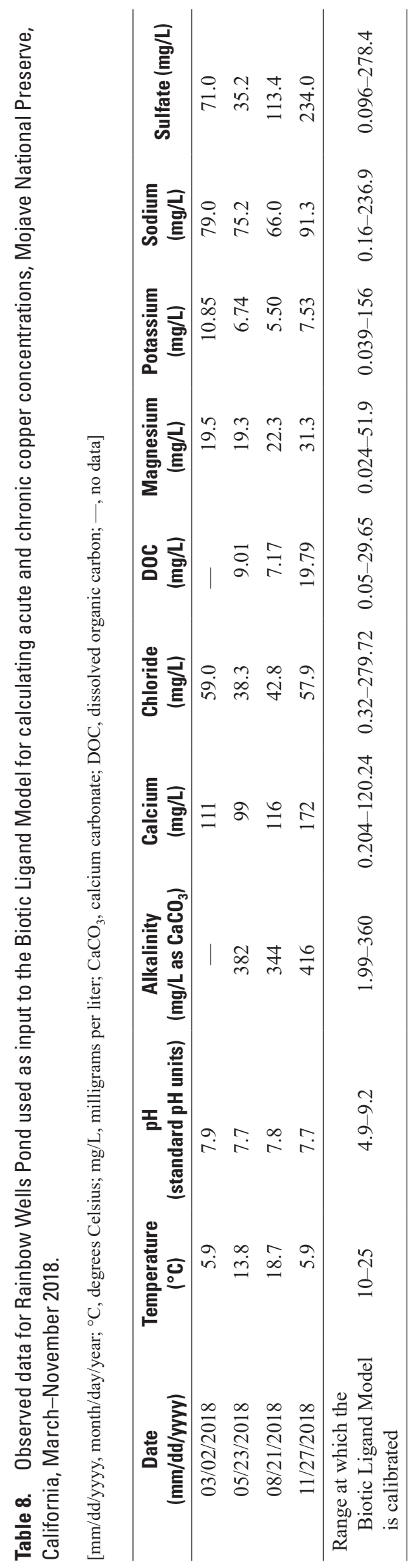


Table 9. Calculated criterion maximum concentration (CMC) and criterion continuous concentration (CCC) values determined by using the U.S. Environmental Protection Agency's Biotic Ligand Model for observed copper concentrations in water samples from Rainbow Wells Pond, Mojave National Preserve, California, March-November 2018.

[mm/dd/yyyy, month/day/year; $\mu \mathrm{g} / \mathrm{L}$, micrograms per liter; $\mathrm{mg} / \mathrm{L}$, milligrams per liter; $\mathrm{CaCO}_{3}$, calcium carbonate; —, not applicable; <, less than]

\begin{tabular}{|c|c|c|c|c|c|c|}
\hline $\begin{array}{c}\text { Date } \\
\text { (mm/dd/yyyy) }\end{array}$ & $\begin{array}{c}\text { Copper } \\
(\mu \mathrm{g} / \mathrm{L})\end{array}$ & $\begin{array}{l}\text { Copper, lab result below } \\
\text { reporting limit ( } \mu \mathrm{g} / \mathrm{L})^{1}\end{array}$ & $\begin{array}{c}\mathrm{pH} \\
\text { (standard } \mathrm{pH} \text { units) }\end{array}$ & $\begin{array}{c}\text { Hardness } \\
\left(\mathrm{mg} / \mathrm{L} \text { as } \mathrm{CaCO}_{3}\right)\end{array}$ & $\begin{array}{c}\text { CMC } \\
\text { (acute; } \mu \mathrm{g} / \mathrm{L} \text { ) }\end{array}$ & $\begin{array}{c}\text { CCC } \\
\text { (chronic; } \mu \mathrm{g} / \mathrm{L} \text { ) }\end{array}$ \\
\hline 03/02/2018 & - & - & - & - & - & - \\
\hline $05 / 23 / 2018$ & $<0.4$ & 0.11 & 7.7 & 327 & 63.6 & 39.5 \\
\hline $08 / 21 / 2018$ & $<2.0$ & 0.16 & 7.8 & 381 & 57.6 & 35.8 \\
\hline $11 / 27 / 2018$ & $<2.4$ & 0.13 & 7.7 & 560 & 139.9 & 86.9 \\
\hline
\end{tabular}

${ }^{1}$ The U.S. Geological Survey National Water Quality Laboratory (USGS NWQL) provides an analytically derived concentration even if analytical results are below laboratory quantification limits.

Table 10. Volatile organic compound concentrations in water from Rainbow Wells Pond, Mojave National Preserve, California, August 21, 2018.

[The detection limit for all constituents is $0.10 \mu \mathrm{g} / \mathrm{L}$. Sampled VOC constituents that were below detection limit can be found on the National Water Information System website, https://doi.org/10.5066/F7P55KJN. Abbreviations: $\mu \mathrm{g} / \mathrm{L}$, micrograms per liter; VOC, volatile organic compound; EPA, U.S. Environmental Protection Agency; —, no data]

\begin{tabular}{lcc}
\hline \multicolumn{1}{c}{ VOC } & $\begin{array}{c}\text { EPA chronic aquatic } \\
\text { value }(\boldsymbol{\mu} \mathbf{g} / \mathbf{L})\end{array}$ & $\begin{array}{c}\text { Rainbow Wells } \\
\text { Pond }(\boldsymbol{\mu g} / \mathbf{L})\end{array}$ \\
\hline Bromodichloromethane & - & 0.12 \\
Styrene & 32 & 0.25 \\
Trichloromethane & 140 & 0.15 \\
\hline
\end{tabular}




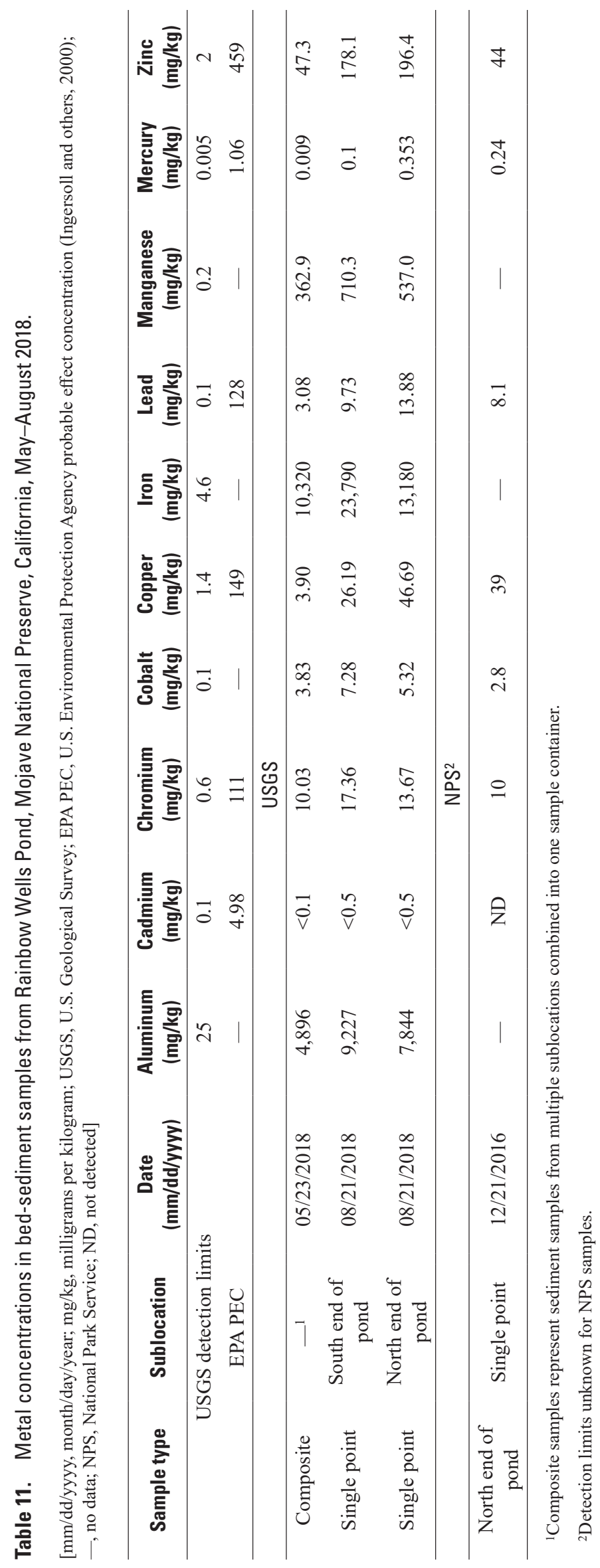




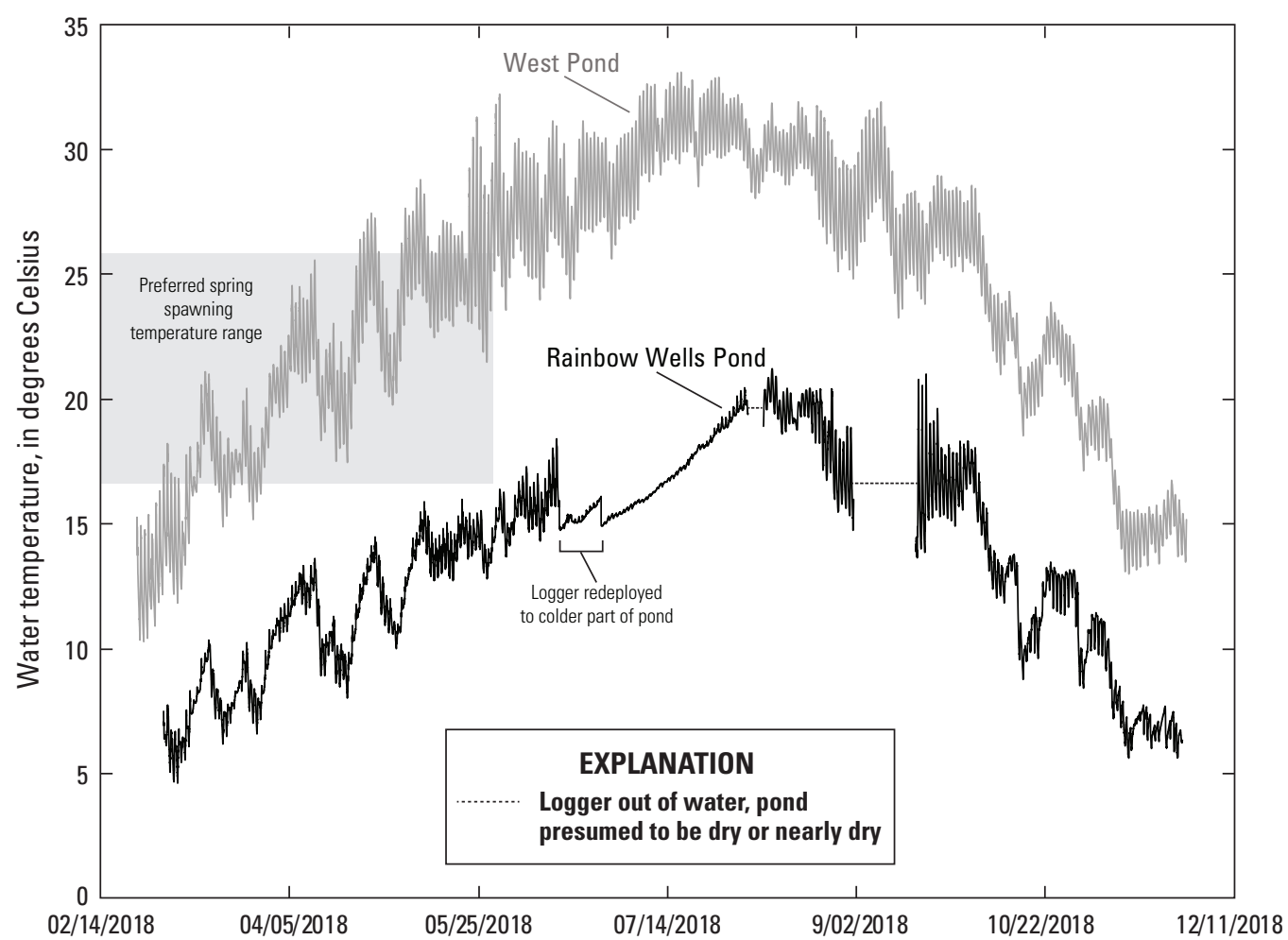

Figure 4. Continuous water temperature in Rainbow Wells Pond and West Pond, Mojave National Preserve, California, February-November 2018.

Alkalinity, as expressed in milligrams per liter of calcium carbonate $\left(\mathrm{CaCO}_{3}\right)$, was measured at every site during each seasonal sampling except on March 2, 2018, at Rainbow Wells Pond and November 28, 2018, at Lake Tuendae and MC Spring (table 4). Alkalinity is a measure of a water's ability to resist changes in $\mathrm{pH}$, and carbonate and bicarbonate, components of alkalinity, can reduce the toxicity of some heavy metals (U.S. Environmental Protection Agency, 1986). The lowest acceptable alkalinity for freshwater aquatic life is $20 \mathrm{mg} / \mathrm{L} \mathrm{CaCO}_{3}$ and the freshwater criterion continuous concentration (CCC) for alkalinity is $20,000 \mathrm{mg} / \mathrm{L}$ as $\mathrm{CaCO}_{3}$ (U.S. Environmental Protection Agency, 1986, 2019). All alkalinities measured for this study were within these limits (122 to $416 \mathrm{mg} / \mathrm{L}$ as $\mathrm{CaCO}_{3}$ ) and did not change by more than 25 percent during the year of monitoring.

Dissolved oxygen (DO) was measured at all sites in May, August, and November 2018 (table 4). During the initial February-March quarterly sampling, DO was not measured because of an instrument malfunction. The DO value of $0.06 \mathrm{mg} / \mathrm{L}$ measured at Rainbow Wells Pond in August 2018 was effectively a $0 \mathrm{mg} / \mathrm{L}$ concentration. Rainbow Wells Pond was likely anoxic at that time as a result of a combination of stagnant inflow, warmer water holding less dissolved gas, and increased density of the cattail stands. Aquatic ecosystems that are dominated by monotypic cattail stands have been shown to have less dissolved oxygen because of litter accumulation and decomposition, less mixing because of blocked wind, and less sunlight penetration for photosynthesis (Albertsen, 2016). The higher dissolved oxygen values recorded at Lake Tuendae on August 22, $2018(14.56 \mathrm{mg} / \mathrm{L})$, and at West Pond on November 28, $2018(15.57 \mathrm{mg} / \mathrm{L})$, were the result of the pond inflow pumps running at the time of sampling. Although water-quality measurements during periods of pumping would usually be considered biased and not included in the results, both Lake Tuendae and West Pond were pumped nearly every other day in 2018 , so the DO values during pumping reflect common environmental conditions.

\section{Continuous Temperature}

Continuous temperature was measured in Rainbow Wells Pond and West Pond to document maximum summer temperatures and spring spawning-season temperatures (fig. 4). The observed continuous water-temperature data for West Pond and Rainbow Wells Pond from February to November 2018 were compared to the temperature requirements of the Mohave tui chub. The Mohave tui chub can generally tolerate temperatures ranging from 3 to 36 degrees Celsius $\left({ }^{\circ} \mathrm{C}\right)$ and prefer spawning temperatures in spring months between 17 and $26^{\circ} \mathrm{C}$ (Vickers, 1973; U.S. Fish and Wildlife Service, 1984; McClanahan and others, 1986). Water temperatures at West Pond ranged from 10.4 to $33.1{ }^{\circ} \mathrm{C}$ during the study. The average diurnal variation in West Pond was around $\pm 3{ }^{\circ} \mathrm{C}$. 
At Rainbow Wells Pond, temperatures steadily rose from a low of $4.6{ }^{\circ} \mathrm{C}$ on March 6,2018 , to a high of $21.2{ }^{\circ} \mathrm{C}$ on August 10, 2018. Diurnal variations of $\pm 3^{\circ} \mathrm{C}$ were recorded until June 15, 2018, when the continuous record indicates an abrupt drop in temperature. During a field visit on June 15, the sensor was redeployed to a deeper area of the pond and the diurnal variation reduced to about $\pm 0.2^{\circ} \mathrm{C}$. Deep water buffers temperature changes more effectively than shallow, so smaller diurnal variations were expected. Prior to June 15, the logger was deployed by using a cable along the bottom of the pond in water about 30-cm-deep water. The purpose of deploying the loggers along a cable at the bottom of the pond was to ensure that the loggers remained under water for the longest time possible. On June 15, the cable was lengthened, and the logger was deployed less than $2 \mathrm{~m}$ from the original location in water more than $60 \mathrm{~cm}$ deep. The exact depth of the water could not be determined at the time of sampling because of large debris in the water, but was estimated to be $60-120 \mathrm{~cm}$ deep. The smaller offset in temperature observed in the continuous record on June 26 was likely because the sensor was disturbed during a field visit. The record also indicates that the water had receded to such a level that the loggers were exposed to air during periods in August and September. Diurnal variations increased to $\pm 9.0^{\circ} \mathrm{C}$ from August 4 to August 8 and September 1 to September 17. These large variations represent air temperature and not water temperature; therefore, these periods of the record were rejected.

\section{Nutrient and Major lons Chemistry}

Phosphorus is a critical element to life, but its overabundance can lead to eutrophication of natural water bodies and can be detrimental to aquatic life (U.S. Environmental Protection Agency, 2017). In 2000, the EPA established ecoregion-scale nutrient criteria to prevent the eutrophication of waters (U.S. Environmental Protection Agency, 2002). The EPA Aggregate Ecoregion III recommended criterion of total phosphorus (TP) for the prevention of eutrophication is $0.017 \mathrm{mg} / \mathrm{L}$ (U.S. Environmental Protection Agency, 2001). Total phosphorus concentrations at MC Spring (0.006-0.023 $\mathrm{mg} / \mathrm{L})$, West Pond (0.014-0.032 mg/L), Lake Tuendae (0.024-0.050 mg/L), and Rainbow Wells Pond (0.116-0.152 $\mathrm{mg} / \mathrm{L})$ exceeded this recommended criterion (table 5). Eutrophic conditions were noted by field personnel on August 21, 2018, and November 27, 2018, at Rainbow Wells Pond. Morning Star Mine had relatively low total phosphorus concentrations (less than $0.004-0.010 \mathrm{mg} / \mathrm{L}$, where "less than" indicates a result that was below the laboratory detection limit).

The EPA recommended criterion for total nitrogen (TN) is $0.40 \mathrm{mg} / \mathrm{L}$ for Aggregate Ecoregion III lakes and reservoirs (U.S. Environmental Protection Agency, 2001; table 5). Total nitrogen is a calculated value and is the sum of Kjeldahl nitrogen (unfiltered ammonia plus organic nitrogen) and nitrate-nitrite (Rus and others, 2012). Total nitrogen concentrations in water from MC Spring $(0.25-1.28 \mathrm{mg} / \mathrm{L})$, West Pond (less than $0.11-1.10 \mathrm{mg} / \mathrm{L}$ ), Lake Tuendae (0.84-1.29 mg/L), and Rainbow Wells Pond (less than 1.00-less than $1.13 \mathrm{mg} / \mathrm{L}$, where a "less than" value for TN indicates that one of the compounds in the calculation was below the laboratory detection limit) exceeded this criterion on at least one occasion, indicating that those habitats may be susceptible to eutrophication. Total nitrogen concentrations at Morning Star Mine (0.24-less than $0.37 \mathrm{mg} / \mathrm{L})$ were below the criterion.

Total dissolved solids (TDS) are a measure of dissolved salts, and the dissolution of evaporites in desert settings can result in very high TDS values - generally between 1,000 to greater than $10,000 \mathrm{mg} / \mathrm{L}$ in basin-fill aquifers along the Mojave River (Thiros and others, 2014). Concentrations of TDS in water samples collected as part of this study ranged from 560 to $2,730 \mathrm{mg} / \mathrm{L}$ (table 6). The TDS concentrations in Rainbow Wells Pond (560-940 mg/L) were less than in MC Spring (1,800-1,860 mg/L), Lake Tuendae $(2,480-2,730 \mathrm{mg} / \mathrm{L})$, West Pond (2,280-2,700 mg/L) and Morning Star Mine (2,030-2,300 mg/L). The relatively low TDS water in Rainbow Wells Pond indicates a short residence time for water moving through the weathered granitic bedrock of the perched aquifer before entering the pond (Thiros and others, 2014). Further studies would be required to accurately determine the age and provenance of the water entering Rainbow Wells Pond.

Measurements of dissolved calcium and magnesium concentrations ranged from 9.9 to $258 \mathrm{mg} / \mathrm{L}$ and 4.4 to $132 \mathrm{mg} / \mathrm{L}$, respectively, in samples from all sites during the study (table 6). Higher concentrations of calcium were found at Rainbow Wells Pond and Morning Star Mine than at the Zzyzx sites. The highest magnesium concentrations, 121-132 mg/L, were measured at Morning Star Mine. These elements are correlated with water hardness and can reduce the toxicity of heavy metals in water (U.S. Environmental Protection Agency, 1986). The geochemical composition of Rainbow Wells Pond is dominated by calcium-bicarbonate, which is characteristic of groundwater in granitic rocks (table 6; Feth and others, 1964).

\section{Metals and Trace Elements}

Twenty-three trace elements were analyzed from water samples collected at Rainbow Wells Pond and Morning Star Mine (table 7). Trace-element concentrations generally did not exceed established EPA freshwater criterion continuous concentration (CCC) for aquatic life (U.S. Environmental Protection Agency, 2019). The one exception was the iron concentration of 2,253 $\mu \mathrm{g} / \mathrm{L}$ in Rainbow Wells Pond on November 27, 2018 (table 6), which exceeded the EPA CCC for iron of 1,000 $\mu \mathrm{g} / \mathrm{L}$ (U.S. Environmental Protection Agency, 1986). Iron and manganese concentrations were higher in water samples collected from Rainbow Wells Pond relative 
to Morning Star Mine (table 6), most likely as a result of the presence of scrap-metal and old cars in the pond. The combination of the relatively high concentrations of iron and manganese and low dissolved oxygen indicate anaerobic conditions in Rainbow Wells Pond.

\section{Other Constituents}

The smell of rotten eggs, which is indicative of anaerobic conditions producing hydrogen sulfide, was documented during field sampling in August and November 2018 at Rainbow Wells Pond. Although a field test for hydrogen sulfide was run onsite, the resulting concentrations were at or below detection limit; however, these field results were rejected because of possible hydrogen sulfide degassing during sampling or analysis.

Samples for cyanide, which was historically used in the mining industry to separate gold from the host rock, were collected from the two historical mining sites, Rainbow Wells Pond and Morning Star Mine (table 7). Cyanide is generally classified in three analytical complexes: total, available (or weak acid dissociable), and free cyanide. The EPA has established an aquatic criterion of $5.2 \mu \mathrm{g} / \mathrm{L}$ only for free cyanide, which is the bioavailable toxic form of cyanide (U.S. Environmental Protection Agency, 1985). Total cyanide and available cyanide methods can be used as proxies for free cyanide in quantities less than $200 \mu \mathrm{g} / \mathrm{L}$ (U.S. Environmental Protection Agency, 2016b). Total cyanide was sampled at Rainbow Wells Pond and Morning Star Mine on March 2, 2018, and both analysis results were below the reporting limit of $10 \mu \mathrm{g} / \mathrm{L}$. Available cyanide, which has a reporting limit of $2 \mu \mathrm{g} / \mathrm{L}$, was sampled at Rainbow Wells Pond on August 21, 2018 , and the resulting concentration of $0.85 \mu \mathrm{g} / \mathrm{L}$ was well below the EPA chronic aquatic exposure limit of $5.2 \mu \mathrm{g} / \mathrm{L}$. The available cyanide value of $0.85 \mu \mathrm{g} / \mathrm{L}$ is reported with a qualifier in table 7, indicating that the analyte concentration was less than the reporting limit but was greater than or equal to the established method detection limit; thus, greater uncertainty is associated with this result.

The Biotic Ligand Model was used to estimate the copper CMC and CCC for Rainbow Wells Pond. The Biotic Ligand Model was run in toxicity mode using the U.S. Environmental Protection Agency water-quality criterion for freshwater. Alkalinity and calcium used in the model slightly exceeded the range of conditions for which the Biotic Ligand Model was developed and calibrated, but the model is still considered valid because those ranges were experimental (table 8). Measured copper concentrations for Rainbow Wells Pond ranged from less than 0.4 to $0.5 \mu \mathrm{g} / \mathrm{L}$. Calculated acute criterion maximum concentrations (CMC) were similar for both May and August 2018 because observed water-chemistry conditions in Rainbow Wells Pond were similar on both dates (table 9). The CCC values also showed a similar pattern in May and August 2018. The CMC and CCC values increased from August to November, reflecting higher alkalinity, calcium, magnesium, and dissolved organic carbon concentrations (tables 8, 9), which help buffer harmful levels of copper. In all cases, the estimated concentration of copper from the ligand model was below a level expected to elicit a harmful response.

Water samples collected in August 2018 from

Rainbow Wells Pond were analyzed for 61 VOCs, of which 3 were detected: trichloromethane (chloroform), bromodichloromethane, and stryrene (table 10).

Chloroform and other trihalomethanes (THMs), including bromodichloromethane, are byproducts commonly produced during the chlorination of water and wastewater (Ivanhnenko and Zogorski, 2006). Styrene is a plastic byproduct

(National Center for Biotechnology Information, 2020). The concentrations of chloroform $(0.15 \mu \mathrm{g} / \mathrm{L})$, styrene $(0.25 \mu \mathrm{g} / \mathrm{L})$, and bromodichloromethane $(0.12 \mu \mathrm{g} / \mathrm{L})$ were well below the respective chronic aquatic values for chloroform $(140 \mu \mathrm{g} / \mathrm{L})$ and styrene (32 $\mu \mathrm{g} / \mathrm{L}$; table 10; Skalski, 1997, 2006); no aquatic criterion exists as of 2019 for bromodichloromethane.

\section{Bed Sediment}

Bed-sediment samples were collected from Rainbow Wells Pond in May (composite sample) and August (single-point samples) 2018 (table 11). Sediment was unlikely to be affected by seasonal variability, so samples were not collected during every visit. Sediment collected from the northern sublocation of the pond generally contained decomposed granite pebbles of sub-centimeter size. Sediment collected from the southern subsection was made up of decomposed-granite pebbles and finer silt and included more organic material, such as decomposing vegetation. The southern subsection is inundated with water during the winter and spring season, but both sediment samples were collected when the water level was below the winter maximum water level (table 4). Results of all sediment analyses showed metal concentrations less than the bed sediment probable-effect concentrations (PEC), the concentrations above which harmful effects are likely to be observed (Ingersoll and others, 2000).

For purposes of comparison, a sample was collected on August 21, 2018, from the north end of the pond at a similar sublocation as a sample collected by the NPS on December 21, 2016. Metal concentrations appear to have increased from 2016 to 2018. Mercury, the constituent of concern in the NPS study, was measured at higher concentrations during 2018 $(0.353 \mathrm{mg} / \mathrm{kg})$ than $2016(0.24 \mathrm{mg} / \mathrm{kg})$. These concentrations, however, were both less than the EPA's established PEC for mercury of $1.06 \mathrm{mg} / \mathrm{kg}$. Differences in metal concentrations between the 2016 NPS sample and 2018 USGS composite sample were greater than differences between the NPS and USGS single-point sample concentration. The 2018 composite USGS sample concentrations were either nearly equal to the 2016 NPS sample concentrations (chromium, zinc) or less than the 2016 NPS sample concentrations (copper, lead, mercury). Cobalt was the only metal measured in sediment 
at a much higher concentration in 2018 than in 2016. The difference between the USGS composite and single-point samples is a further indication of lateral heterogeneity in the pond sediment. All the NPS and USGS single-point and composite bed-sediment sample concentrations at Rainbow Wells Pond were below the EPA PEC levels.

\section{Suitability of Potential Habitats: Rainbow Wells Pond and West Pond}

\begin{abstract}
Rainbow Wells Pond and West Pond were identified by the National Park Service as potential Mohave tui chub habitats. The suitability of potential habitats for the Mohave tui chub is dependent on configuration, ecology, and water quality (U.S. Fish and Wildlife Service, 1984, 2009; Feldmeth and Soltz, 1985; Archbold, 1996). The Mohave tui chub can generally tolerate temperatures ranging from 3 to $36^{\circ} \mathrm{C}$ but prefer minimum spring-spawning temperatures of $18^{\circ} \mathrm{C}$ (Vickers, 1973; McClanahan and others, 1986). Successful spawning, however, has been documented in temperature ranges from 17 to $26^{\circ} \mathrm{C}$ (U.S. Fish and Wildlife Service, 1984). The Mohave tui chub is a tolerant species that has been observed in springs near Zzyzx to survive in water having dissolved oxygen concentrations of less than $1 \mathrm{mg} / \mathrm{L}$, a $\mathrm{pH}$ between 9 and 10, and conductivity of $18,000 \mu \mathrm{S} / \mathrm{cm}$ (U.S. Fish and Wildlife Service, 1984). A minimum water depth of $1.2 \mathrm{~m}$ has been identified as necessary to prevent rampant cattail growth and to meet dissolved oxygen and temperature requirements (U.S. Fish and Wildlife Service, 2009). Water-quality results for the three existing Mohave tui chub habitats in Mojave National Preserve (MC Spring, Lake Tuendae, and Morning Star Mine) indicate that the water quality is within published tolerances for a suitable Mohave tui chub habitat.
\end{abstract}

\section{Rainbow Wells Pond}

Data collected during this study indicate that some water-quality and water-level conditions at Rainbow Wells Pond were not consistently within published tolerances for Mohave tui chub. Although the general water and sediment chemistry of Rainbow Wells Pond compared well to the other established Mohave tui chub sites and published criteria, the water temperature, water-depth, and dissolved oxygen concentrations may not be suitable for Mohave tui chub habitat.

The water temperature at Rainbow Wells Pond in spring 2018 was below normal spring temperatures required for successful Mohave tui chub spawning (fig. 4; U.S. Fish and Wildlife Service, 1984). Water temperatures did not rise to the critical $18^{\circ} \mathrm{C}$ needed for spawning until mid-June, after the typical spawning season is over. Although the water temperatures during the March to November period of record stayed within absolute thresholds for Mohave tui chub survival of roughly $3-36{ }^{\circ} \mathrm{C}$, winter water temperatures for DecemberFebruary were not recorded because of time constraints of the study and are unknown. Based on visual trends of temperature change in spring through fall 2018 (fig. 4), however, continued declines in temperature below the low of $4{ }^{\circ} \mathrm{C}$ in late February were likely, increasing the possibility of falling below the minimum water temperature typically required for Mohave tui chub survival (Feldmeth and Soltz, 1985).

The continuous temperature data show periods in August and September during which the sensor is believed to have been out of water (fig. 4). During this period, the water level was below the required minimum depth of $1.2 \mathrm{~m}$ during the hottest part of the year (U.S. Fish and Wildlife Service, 2009), indicating a less suitable or possibly unsuitable habitat for Mohave tui chub. Moreover, low water levels during the summer months of the study indicate that during warmer and drier years than 2018, water levels could be lowered to the extent that Rainbow Wells Pond could exhibit completely dry conditions.

Low dissolved oxygen concentrations in Rainbow Wells Pond during August 2018 indicate that the pond likely was eutrophic. Although published literature has documented living Mohave tui chub in environments having less than $1 \mathrm{mg} / \mathrm{L}$ dissolved oxygen (McClanahan and others, 1986), other studies found fish mortality at or above DO concentrations of $1 \mathrm{mg} / \mathrm{L}$ (Feldmeth and Soltz, 1985). Rainbow Wells Pond consistently had low DO concentrations and, at one point during 2018, had effectively no dissolved oxygen $(0.06 \mathrm{mg} / \mathrm{L}$, table 4$)$. Dissolved oxygen concentrations were similar in all parts of the pond, including the open, cattail-free area where DO would be expected to be highest. The DO concentrations in Rainbow Wells Pond were at or below the published minimum values for suitable Mohave tui chub habitat on the May 23 and August 21, 2018, indicating the pond potentially had low oxygen concentrations during several months of the year (fig. 4).

\section{West Pond}

The water chemistry of West Pond appears to have stabilized following restoration of the pond in 2015, and water-quality conditions in 2018 were within published tolerances for suitable Mohave tui chub habitat. The measurements of specific conductance at West Pond $(3,850-4,730 \mu \mathrm{S} / \mathrm{cm})$ were within the range of measurements made at other habitats evaluated $(720-5,260 \mu \mathrm{S} / \mathrm{cm})$. The results of this study show that since restoration in 2015 , specific conductance and dissolved solids concentrations in West Pond have stabilized (table 4; National Park Service, 2018), which is consistent with NPS management goals of restoring the water quality and aquatic conditions of the pond.

Additional water-quality criteria that support the suitability of West Pond as a potential Mohave tui chub habitat include the similarity of water chemistry of West 
Pond to that of Lake Tuendae, where Mohave tui chub have been successfully established. Comparison of constituent concentrations in West Pond and Lake Tuendae show similar seasonal variations. Specific conductance values $(3,851-5,261 \mu \mathrm{S} / \mathrm{cm})$ and total dissolved solids (2,280-2,730 $\mathrm{mg} / \mathrm{L}$ ) concentrations were similar in the two habitats (tables 4 and 6). Nutrient results, as expressed by nitrogen and phosphorus species, were below EPA recommended criterion for freshwater lakes and reservoirs (U.S. Environmental Protection Agency, 2001). The $\mathrm{pH}$ values for both sites were at and above the upper range of acceptable $\mathrm{pH}$ for aquatic life. In shallow, biologically active waters, $\mathrm{pH}$ has been shown to have a large diurnal range resulting from photosynthesis, and aquatic species in these environments are documented to have adapted to that range (European Inland Fisheries Advisory Commission, 1969). The population of Mohave tui chub in Lake Tuendae is considered stable, but monitoring of $\mathrm{pH}$ could assist in maintaining the Mohave tui chub population there and the future population in West Pond.

\section{References Cited}

Albertsen, A.J., 2016, Impacts of the amount of hybrid cattail (Typha $x$ glauca) litter on abiotic and biotic conditions in prairie pothole wetlands: Ames, Iowa, Iowa State University, M.S. thesis, 73 p.

Archbold, C.A., 1996, Habitat evaluation for the Mohave tui chub (Gila bicolor mohavensis): Fullerton, California, California State University, M.S. thesis, 99 p.

Archdeacon, T.P., 2007, Effects of Asian tapeworm, mosquitofish, and food ration on Mohave tui chub growth and survival: Tucson, Arizona, University of Arizona, M.S. thesis, $77 \mathrm{p}$.

Bailard, J., and Moret, G., 2015, Reconstructing the water level record at MC Spring since 1990Mojave National Preserve: Natural Resource Report NPS/MOJN/NRR_-2015/1006, 41 p., https://doi.org/10.13140/RG.2.2.27104.89609.

Barthel, P.S., 2008, Water budget and hydrogeologic model of spring flow at Limestone Hill, Zzyzx Desert Studies Center: Fullerton, California, California State University, Master's thesis, 113 p., https://www.nps.gov/moja/learn/nature/ upload/Barthelthesis-2.pdf.

Chen Y., Parmenter, S., and May, B., 2012, Genetic characterization and management of the endangered Mohave tui chub: Conservation Genetics, v. 14, no. 1, p. 11-20, https://doi.org/10.1007/s10592-012-0410-6.
Cultural Systems Research, Inc., 2002, The Native Americans of Joshua Tree National Park-An ethnographic overview and assessment study: National Park Service, accessed August 5, 2019, at https://www.nps.gov/parkhistory/online_ books/jotr/history5.htm.

Desert Fish Habitat Partnership, 2016, Mohave tui chub habitat restoration-West Pond and Rainbow Wells, final completion report: accessed August 5, 2021, at https://www.desertfhp.org/project-summaries-page-2.

Desert Studies Center, 2019, About soda springs, the Zzyzx era: Fullerton, California State University, accessed March 11, 2020, at http://nsm.fullerton.edu/desert-studies-about.

Di Toro, D.M., Allen, H.E., Bergman, H.L., Meyer, J.S., Paquin, P.R., and Santore, R.C., 2001, Biotic Ligand Model of the acute toxicity of metals, 1. Technical basis: Environmental Toxicology and Chemistry, v. 20, no. 10, p. 2383-2396, https://doi.org/10.1002/etc.5620201034.

European Inland Fisheries Advisory Commission, 1969, Water quality criteria for European freshwater fish-extreme $\mathrm{pH}$ values and inland fisheries: Water Research, v. 3, no. 8, p. 593-611, https://doi.org/10.1016/0043-1354(69)90048-7.

Feldmeth, C.R., and Soltz, D.L., 1985, An examination of potential relocation sites of the Mohave tui chub (Gila bicolor mohavensis): Report prepared for U.S. Bureau of Land Management by Ecological Research Services, 38 p.

Feth, J.H., Roberson, C.E., and Polzer, W.L., 1964, Sources of mineral constituents in water form granitic rocks Sierra Nevada California and Nevada, geochemistry of water: U.S. Geological Survey Water Supply Paper 1535-I, 70 p., https://doi.org/10.3133/wsp1535I.

Garbarino, J.R., Kanagy, L.K., and Cree, M.E., 2006, Determination of elements in natural-water, biota, sediment, and soil samples using collision/reaction cell inductively coupled plasma-mass spectrometry: U.S. Geological Survey Techniques and Methods, book 5, chap. B1, 87 p., https://doi.org/10.3133/tm5b1.

Hach, 2009, Sulfide USEPA Methylene Blue, Method 8131, DR/800: DOC316.53.01136, ed. 9, 6 p., https://www .hach.com/asset-get.download.jsa?id=7639983902.

Henkanaththegedara, S.M., 2012, Ecological complexity of non-native species impact in desert aquatic systems: Fargo, North Dakota State University, Ph.D. dissertation, 147 p., https://www.nps.gov/moja/learn/nature/upload/ Henkanaththegedara_Ph-D-dissertation_March2012_v2.pdf. 
Hubbs, C.L., and Miller, R.R., 1943, Mass hybridization between two genera of cyprinid fishes in the Mohave Desert, California: Papers of the Michigan Academy of Science, Arts and Letters, v. 28, p. 343-378.

Hughson, D., and Woo, D., 2004, Report on a workshop to revisit the Mohave tui chub recovery plan and a management action plan: National Park Service, 72 p., https://www.nps.gov/moja/learn/nature/upload/ ACF46F1.pdf.

Hwang, P.-P., Lee, T.-H., and Lin, L.-Y., 2011, Ion regulation in fish gills-Recent progress in the cellular and molecular mechanisms: American Journal of Physiology. Regulatory, Integrative and Comparative Physiology, v. 301, no. 1, p. R28-R47, https://doi.org/10.1152/ajpregu.00047.2011.

Hydrolab, 2019, HL series sensors user manual (4th ed.): Hydrolab, DOC026.97.80349, 400 p., accessed February 21, 2020, at https://www.ott.com/en-us/products/download/ hl-series-sensors-bedienungsanleitung-user-manual-manueldutilisation-manual-de-usuario/.

Ingersoll, C., MacDonald, D., Wang, N., Crane, J., Field, L., Haverland, P., Kemble, N., Lindskoog, R., Severn, C., and Smorong, D., 2000, Prediction of sediment toxicity using consensus-based freshwater sediment quality guidelines: Prepared by U.S. Geological Survey for U.S. Environmental Protection Agency Great Lakes National Program Office (GLNPO), Chicago, EPA 905/R-00/007, 33 p.

Ivanhnenko, T., and Zogorski, J.S., 2006, Sources and occurrence of chloroform and other trihalomethanes in drinking-water supply wells in the United States, 1986-2001: U.S. Geological Survey Scientific Investigations Report 2006-5015, 13 p., https://doi.org/10.3133/sir20065015.

Lovich, J., and Meyer, K., 2002, The western pond (Clemmys marmorata) in the Mojave River, California, USA: highly adapted survivor or tenuous relict?: Journal of Zoology, v. 256, no. 4, p. 537-545, https://doi.org/10.1017/S0952836902000584.

McClanahan, L., Feldmeth, C.R., Jones, J., and Soltz, D.L., 1986, Energetics, salinity and temperature tolerance in the Mohave tui chub, Gila bicolor mohavensis: Copeia, v. 1986, no. 1, p. 45-52, https://doi.org/10.2307/1444886.

McGeer, J.C., Szebedinszky, C., McDonald, D.G., and Wood, C.M., 2002, The role of dissolved organic carbon in moderating the bioavailability and toxicity of $\mathrm{Cu}$ to rainbow trout during chronic waterborne exposure: Comparative Biochemistry and Physiology Part C-Toxicology and Pharmacology, v. 133, nos. 1-2, p. 147-160, https://doi.org/10.1016/S1532-0456(02)00084-4.
Mendenhall, W.C., 1909, Some desert watering places in southeastern California and southwestern Nevada: U.S. Geological Survey Water Supply Paper 224, 98 p., https://doi.org/10.3133/wsp224.

Miller, R.R., 1936, Classification of a Mojave river fish: Claremont, Calif., Pomona College, Journal of Entomology and Zoology, v. 28, p. 58-59.

Mueller, D.K., Schertz, T.L., Martin, J.D., and Sandstrom, M.W., 2015, Design, analysis, and interpretation of field quality-control data for water-sampling projects: U.S. Geological Survey Techniques and Methods, book 4, chap. C4, 54 p., https://doi.org/10.3133/tm4C4.

National Center for Biotechnology Information, 2020, Styrene compound summary: PubChem Database, $\mathrm{CID}=7501$, accessed March 6, 2020, at https://pubchem.ncbi.nlm.nih.gov/compound/Styrene.

National Park Service, 2015, Remove decaying vegetation from pond at Rainbow Wells: Categorical Exclusion prepared by the Mojave National Park, no. 15-moja-033/ PEPC 58884, accessed September 9, 2020, at https://parkplanning.nps.gov/document.cfm?parkID= $322 \&$ projectID $=58884 \&$ documentID $=66732$.

National Park Service, 2018, Management plan for developed water resources and environmental assessment, Mojave National Preserve, 179 p., https:/parkplannin g.nps.gov/document.cfm?parkID=322\&projectID $=$ $32532 \&$ documentID $=86685$.

O.I. Analytical, 2009, An overview and comparison of methods for cyanide analysis: Publication 32720509, accessed February 21, 2020, at https:/www.waterboar ds.ca.gov/coloradoriver/water_issues/programs/npdes/docs/ oi_analysis.pdf.

Omernik, J.M., and Griffith, G.E., 2014, Ecoregions of the conterminous United States, evolution of a hierarchical spatial framework: Environmental Management, v. 54, no. 6, p. 1249-1266, https://doi.org/10.1007/s00267-014-0364-1.

Pagenkopf, G.K., 1983, Gill surface interaction model for trace-metal toxicity to fishes-Role of complexation, pH, and water hardness: Environmental Science and Technology, v. 17, no. 6, p. 342-347, https://doi.org/10.1021/es00112a007. 
Paquin, P.R., Gorsuch, J.W., Apte, S., Batley, G.E., Bowles, K.C., Campbell, P.G.C., Delos, C.G., Di Toro, D.M., Dwyer, R.L., Glavez, F., Gensemer, R.W., Goss, G.G., Hogstrand, C., Janssen, C.R., McGeer, J.C., Naddy, R.B., Playle, R.C., Santore, R.C., Schneider, U., Stubblefield, W.A., Wood, C.M., and Wu, K.B., 2002, The biotic ligand model-A historical overview: Comparative Biochemistry and Physiology Part CToxicology and Pharmacology, v. 133, nos. 1-2, p. 3-35, https://doi.org/10.1016/S1532-0456(02)00112-6.

Parent, L., Twiss, M.R., and Campbell, P.G.C., 1996, Influences of natural dissolved organic matter on the interaction of aluminum with the microalga Chlorella-A test of the free-ion model of trace metal toxicity: Environmental Science \& Technology, v. 30, no. 5, p. 1713-1720, https://doi.org/10.1021/es950718s.

RTI Laboratories, 2019, Listed analytical methods: RTI Laboratories web page, accessed June 17, 2019, at https://rtilab.com/techniques/methods/.

Rus, D.L., Patton, C.J., Mueller, D.K., and Crawford, C.G., 2012, Assessing total nitrogen in surface-water samplesPrecision and bias of analytical and computational methods: U.S. Geological Survey Scientific Investigations Report 2012-5281, 38 p., https://doi.org/10.3133/sir20125281.

Shelton, L.R., and Capel, P.D., 1994, Guidelines for collecting and processing samples of stream bed sediment for analysis of trace elements and organic contaminants for the national water-quality assessment program: U.S. Geological Survey Open-File Report 94-458, 20 p., https://doi.org/10.3133/ofr94458.

Simons, A., and Mayden, R., 1999, Phylogenetic relationships of North American Cyprinids and assessment of homology of the Open Posterior Myodome: Copeia, v. 1999, no. 1, p. 13-21, https://doi.org/10.2307/1447380.

Skalski, C.J., 1997, Aquatic life fact sheet for Styrene (Aquatic Life-Acute concentration): Ohio Environmental Protection Agency, accessed March 8, 2019, at https:/www.epa.gov/ sites/production/files/2015-06/documents/oh_al_305_ 10301997.pdf.

Skalski, C.J., 2006, Aquatic life fact sheet for Chloroform (Aquatic Life-Acute concentration): Ohio Environmental Protection Agency, accessed March 8, 2019, at https:/www.epa.gov/sites/production/files/2015-06/ documents/oh_al_353_03012006.pdf.

Snyder, J.O., 1918, The fishes of Mohave River, California: Proceeding of the U.S. Natural History Museum, v. 54, no. 2236, p. 297-299, https://doi.org/10.5479/si.00963801.54-2236.297.
Stoffer, P.W., 2004, Desert landforms and surface processes in the Mojave National Preserve and vicinity: U.S. Geological Survey Open-File Report 2004-1007, https://doi.org/10.3133/ofr20041007.

Theodore, T.G., ed., 2007, Geology and mineral resources of the East Mojave National Scenic Area, San Bernardino County, California: U.S. Geological Survey Bulletin 2160, 274 p., https://pubs.usgs.gov/bul/b2160/pdf/B2160v9.pdf.

Thiros, S.A., Paul, A.P., Bexfield, L.M., and Anning, D.W., 2014, The quality of our Nation's waters - Water quality in basin-fill aquifers of the southwestern United StatesArizona, California, Colorado, Nevada, New Mexico, and Utah, 1993-2009: U.S. Geological Survey Circular 1358, 113 p., https://doi.org/10.3133/cir1358.

U.S. Bureau of Reclamation, 2018, Creating refuge for Mohave tui chub at Mojave National Preserve, a case study on restoration, case study handout: U.S. Bureau of Reclamation, accessed August 5, 2019, at https://u sbr.maps.arcgis.com/apps/MapSeries/index.html?appid=ab c9867599674ee280c3ba6395482b5b.

U.S. Environmental Protection Agency, 1985, Ambient water quality criteria for cyanide: U.S. Environmental Protection Agency 440/5-84-028, 59 p.

U.S. Environmental Protection Agency, 1986, Quality criteria for water: U.S. Environmental Protection Agency 440/5-86-001, 395 p.

U.S. Environmental Protection Agency, 2001, Ambient water quality criteria recommendations - Information supporting the development of state and tribal nutrient criteria for lakes and reservoirs in nutrient ecoregion III: U.S. Environmental Protection Agency 822-B-01-008, 142 p., https://www.epa.gov/sites/production/files/ documents/lakes3.pdf.

U.S. Environmental Protection Agency, 2002, Fact sheet ecoregional nutrient criteria: U.S. Environmental Protection Agency 822-F-02-008, https://www.epa.gov/sites/ production/files/2019-02/documents/ecoregional-nutrientcriteria-factsheet-2002.pdf.

U.S. Environmental Protection Agency, 2007, Aquatic life ambient freshwater quality criteria-Copper: U.S. Environmental Protection Agency 822-R-07-001, 204 p., https://www.epa.gov/sites/production/files/2019-02/ documents/al-freshwater-copper-2007-revision.pdf.

U.S. Environmental Protection Agency, 2016a, Copper biotic ligand model: U.S. Environmental Protection Agency, accessed March 3, 2019, at https://www.epa.gov/wqs-tech/copper-biotic-ligand-model. 
U.S. Environmental Protection Agency, 2016b, Cyanide clarification of free and total cyanide analysis for Safe Drinking Water Act (SDWA) compliance: U.S. Environmental Protection Agency 815-B-20-004, 12 p.

U.S. Environmental Protection Agency, 2016c, Draft technical support document-Recommended estimates for missing water quality parameters for application in EPA's Biotic Ligand Model: Office of Water, U.S. Environmental Protection Agency 820-R-15-106, February 2016, https://www.federalregister.gov/documents/2016/02/ 16/2016-03119/draft-technical-support-documentrecommended-estimates-for-missing-water-qualityparameters-for.

U.S. Environmental Protection Agency, 2017, IndicatorsPhosphorus: National Aquatic Resource Surveys, accessed December 3, 2019, at https://www.epa.gov/national-aquaticresource-surveys/indicators-phosphorus.

U.S. Environmental Protection Agency, 2018, Final aquatic life ambient water quality criteria for aluminum-2018: U.S. Environmental Protection Agency 822-R-18-001, 329 p., https://www.epa.gov/sites/production/files/201812/documents/aluminum-final-national-recommendedawqc.pdf.

U.S. Environmental Protection Agency, 2019, National recommended water quality criteria-Aquatic life criteria table: U.S. Environmental Protection Agency, accessed November 15, 2019, at https://www.epa.gov/wqc/ national-recommended-water-quality-criteria-aquatic-lifecriteria-table.

U.S. Fish and Wildlife Service, 1984, Recovery plan for the Mohave tui chub, Gila bicolor mohavensis: Portland, Oregon, U.S. Fish and Wildlife Service, 56 p.

U.S. Fish and Wildlife Service, 2009, Mohave tui chub (Gila bicolor mohavensis $=$ Siphaletes bicolor mohavensis $)$ 5-year review-Status and evaluation: Ventura, California, U.S. Fish and Wildlife Service, Ventura Fish and Wildlife Office, $29 \mathrm{p}$.

U.S. Geological Survey, 2006, Collection of water samples (ver. 2.0): U.S. Geological Survey Techniques of Water-Resources Investigations, book 9, chap. A4, accessed December 18, 2019, at https://pubs.water.usgs.gov/twri9A.
U.S. Geological Survey, 2010, Continuous records processing of all water time series data: Water Resources Discipline Policy Memorandum 2010.02, https://water.usgs.gov/ $\mathrm{admin} / \mathrm{memo} /$ policy/wrdpolicy10.02.html.

U.S. Geological Survey, 2017, Procedures for processing, approving, publishing, and auditing time-series records for water data: Office of Water Quality Technical Memorandum 2017.07, https://water.usgs.gov/osw/time-series-guidance/ SW_2017.10+GW_2017.03+WQ_2017.07.pdf.

U.S. Geological Survey, 2019, National water quality laboratory documents web page: accessed August 5, 2019, at https://www.usgs.gov/labs/nwql/files.

U.S. Geological Survey, variously dated, National field manual for the collection of water-quality data: U.S. Geological Survey Techniques of Water-Resources Investigations, accessed May 9, 2017, at https://water.usgs.gov/owq/ FieldManual/compiled/NFM_complete.pdf.

U.S. Geological Survey, 2021, National Water Information System: U.S. Geological Survey web interface, https://doi.org/10.5066/F7P55KJN.

Vickers, C.E., 1973, Aspects of the life history of the Mohave Chub, Gila bicolor mohavensis (Snyder) from Soda Lake, California: California State University, Fullerton, M.A. thesis, $27 \mathrm{p}$.

Wagner, R.J., Boulger, R.W., Jr., Oblinger, C.J., and Smith, B.A., 2006, Guidelines and standard procedures for continuous water-quality monitors-Station operation, record computation, and data reporting: U.S. Geological Survey Techniques and Methods 1-D3, 51 p. plus 8 attachments, accessed December 2, 2019, at https://doi.org/10.3133/tm1D3.

Windward Environmental, 2017, Biotic ligand model windows ${ }^{\circledR}$ interface, research version 3.16.2.41: User's Guide and Reference Manual, $52 \mathrm{p}$.

Woo, D., and Hughson, D., 2003, Zzyzx mineral springs-cultural treasure and endangered species aquarium: San Diego, Calif., George Wright Society Conference, p. 84-87, http://www.georgewright.org/0320woo.pdf.

YSI, 2012, 6-series multiparameter water quality sondes user manual: YSI Incorporated, 379 p., https://www.ysi.com/ File\%20Library/Documents/Manuals/069300-YSI-6-SeriesManual-RevJ.pdf. 
For more information concerning the research in this report, contact the Nevada Water Science Center

U.S. Geological Survey

2730 N. Deer Run Road

Carson City, Nevada 95819

https://www.usgs.gov/centers/nv-water

Publishing support provided by the U.S. Geological Survey Science Publishing Network, Sacramento Publishing Service Center 


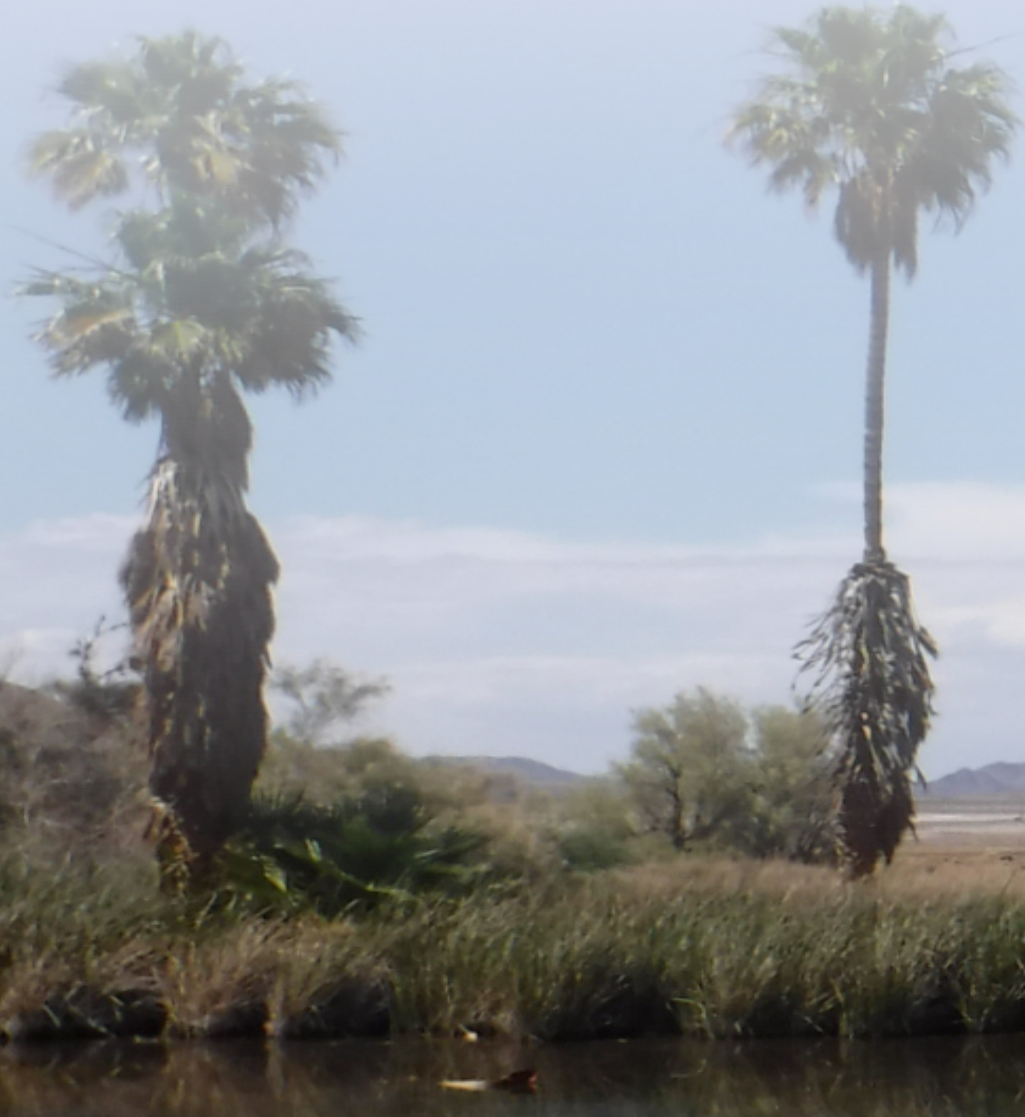

